Article

\title{
Biochar and Biomass Ash as a Soil Ameliorant: The Effect on Selected Soil Properties and Yield of Giant Miscanthus (Miscanthus x giganteus)
}

\author{
Bogdan Saletnik *, Grzegorz Zagula, Marcin Bajcar, Maria Czernicka and Czeslaw Puchalski \\ Department of Bioenergetics and Food Analysis, Faculty of Biology and Agriculture, Rzeszow University, \\ Cwiklinskiej 2D, 35-601 Rzeszow, Poland; g_zagula@ur.edu.pl (G.Z.); mbajcar@ur.edu.pl (M.B.); \\ czernicka.maria@gmail.com (M.C.); cpuchal@ur.edu.pl (C.P.) \\ * Correspondence: bogdan.saletnik@urz.pl; Tel.: +48-177-854-965
}

Received: 15 August 2018; Accepted: 20 September 2018; Published: 22 September 2018

\begin{abstract}
We assess the possibility of using biochar and ash from plant biomass to fertilise giant miscanthus (Miscanthus x giganteus). The paper concerns the optimisation of the combination of fertiliser applications of the aforementioned materials in the context of the plant yield obtained. There was an increase in yield of 8-68\% over the two years of research when compared with the control plots. It was found that the application of biochar, ash from biomass and a combination of the two at appropriate rates as a soil additive can substitute for classic mineral fertilisers and strengthen the ecological aspects of energy crop cultivation. The interpretation of the results obtained enabled the selection of optimum fertiliser applications, resulting in a significant increase in the yield of plants and an improvement in soil chemical properties. It was found that the highest yield of dry matter of giant miscanthus plants, after both the first and second year of cultivation, was obtained by applying the fertiliser containing ash at a rate of $1.5 \mathrm{t} \mathrm{ha}^{-1}$, together with biocarbon and the combination of biochar and ash at a rate of $1.5 \mathrm{tha}^{-1}$.
\end{abstract}

Keywords: biochar; ash from biomass; giant miscanthus; fertilisation

\section{Introduction}

Plant biomass, due to its specific chemical structure and high calorific value, can be used in numerous conversion processes aimed at the production of solid, liquid and gaseous fuels [1]. The acquisition of energy from biomass is possible through its conversion in the form of direct combustion, co-incineration with coal, gasification, pyrolysis, and fermentation [2].

The factors determining the growth performance of biomass in energy crops are the choice of plant species and production cycle, including the location of the plantation and appropriate fertilisation. In turn, the proper preparation of the material and the optimisation of the technological process, including the management of waste products, i.e., ashes generated during combustion, affect the efficiency of using biomass as an energy source. Both the cultivation of energy crops and the utilisation of the ash from biomass are part of sustainable energy management and have a huge impact on the environment. Agroenergy is also recommended from an environmental protection point of view to carry out agrotechnical sanitation in contaminated areas, especially those with toxic metals [3]. Ash from biomass, according to data available in the literature, can favourably affect the physicochemical properties of soils to a comparable or even greater degree than mineral fertiliser [4]. According to the latest research, the effective improvement of the physicochemical properties of soils and the increase in fertility of less fertile soils can be obtained by using biochar. Biochar is a material formed in the process of thermal conversion of biomass under conditions of limited access 
of oxygen, which results in the formation of a product with a high carbon content and very good sorption properties [5]. In addition, it was proven that biochar has high chemical reactivity to organic and inorganic compounds present in the soil environment, and therefore its potential use in the reclamation of chemically degraded soils is more and more frequently discussed. From an agricultural point of view, the introduction of biochar into soils provides many benefits by improving physical, chemical and biological properties, which in turn contributes to an increase in crop yield $[6,7]$.

From an agricultural point of view, the introduction of biochars into soils as agents that improve their properties seems to be beneficial due to the possibility of improving the conditions for the growth, development and increased yield of crops [7]. In addition, in view of the rapid effects and relatively low costs of using them, biochar compounds are more and more often used in the remediation and soil protection process [8]. The performance of biochar introduced into the soil environment mainly depends on the raw materials used for its production, as well as the parameters of the pyrolysis process. They determine the contents of macro- and microelements, as well as harmful substances such as heavy metals. The heterogenous chemical composition of biochars allows their interaction with a large group of inorganic and organic compounds present in the soil [9]. Various properties of these materials allow reactions with mineral and organic particles in the soil, as well as the formation of mineral-organic complexes [10]. Biochars introduced into the soil are characterised by high stability and resistance to biological decomposition, which is why they are considered a highly effective agent of carbon dioxide sequestration in the soil [11]. In addition, the application of biochars not only allows the soil to increase its carbon content, but also other biogenic compounds, such as phosphorus, potassium, magnesium and nitrogen [12,14]. The high ion-exchange capacity and the specific surface of biochars contribute to the reduction of leaching of biogenic elements from the soil environment and reduce the emission of nitrogen oxide [14]. Biochars introduced into the soil as fertiliser materials also affect the increase in soil $\mathrm{pH}$ [15]. The research conducted so far has shown that biochars contain numerous alkaline substances, such as calcium carbonate, which may affect the soil $\mathrm{pH}$, and the best results in the form of $\mathrm{pH}$ increase can be obtained in heavily acidified soils [16,17]. Biochar added to the soil also affects its physical properties by increasing the ability to form soil aggregates and resistance to erosion or improvement in water retention [18]. The improvement of physical properties of soils after the application of the biochar additive mainly depends on its properties, which are predominantly determined by the technology used in its production $[19,20]$. The highly porous structure of biochars can also create a favourable environment for the existence of microorganisms, which results in increased fertility and soil productivity [21].

Giant miscanthus (Miscanthus $\mathrm{x}$ giganteus) is a long-term energy crop, characterised by high yield potential. This impressive grass originates from tropical, subtropical and more temperate areas of Southeast Asia. In its natural environment it can reach 6 meters in height, and the diameter of stiff sprouts can be $20 \mathrm{~mm}$. It has been known in Europe for about 50 years; it was originally treated as an ornamental plant, and then started to be used for energy purposes. This plant is a natural hybrid that was created by crossing Miscanthus sinensis and Miscanthus sacchariflorus. This interspecific hybrid belongs to the group of plants with the C-4 photosynthetic cycle, which is an efficient process of photosynthesis. In the first year of cultivation, the miscanthus can reach a height of about 2 meters and the yield is at the level of $2-5 \mathrm{t} \mathrm{ha}^{-1}$ dry matter. In the second year of cultivation, the plants can reach a height of more than 3 meters and the obtained yield can be at the level of 8-10 $\mathrm{tha}^{-1}$ dry matter. In order to ensure the correct rate of plant growth, it is important to apply an appropriate fertilizer dose in the initial growing period. The maximum potential harvesting of miscanthus starts from the third year of cultivation. High biomass yields, which can reach over $20 \mathrm{t} \mathrm{ha}^{-1}$ of dry matter, can keep to 10 years during harvesting.Biomass from the giant miscanthus is a very high-quality form of 'fuel' intended for direct combustion. It also has high potential as a substrate in bio-oil production, gasification and charring processes [22,23].

The purpose of the paper is to assess the possibility of using biochar and ash formed through the plant biomass combustion process as a fertiliser used in the cultivation of giant miscanthus 
(Miscanthus $\mathrm{x}$ giganteus) and the optimisation of the combination of fertiliser applications. Prior to the studies, the following research problem was formulated: if biochar and ash from plant biomass can be used as a fertiliser in the cultivation of energy crops, which has a positive effect on soil properties and increases crop yields?

\section{Results}

\subsection{Names of Tests}

The tests used for further identification are described by symbols, due to the type and application rate of the fertiliser used:

- B1/P1 (control test-no fertiliser),

- P2 (fertilised with ash at a dose of $1.5 \mathrm{t} \mathrm{ha}^{-1}$ ),

- P3 (fertilised with ash at a dose of $3.0 \mathrm{t} \mathrm{ha}^{-1}$ ),

- P4 (fertilised with ash at a dose of $4.5 \mathrm{tha}^{-1}$ ),

- B2/P1 (fertilised with biochar at a dose of $11.5 \mathrm{tha}^{-1}$ ),

- B2/P2 (fertilised with biochar and ash at doses of 11.5 and $1.5 \mathrm{t} \mathrm{ha}^{-1}$, respectively),

- B2/P3 (fertilised with biochar and ash at doses of 11.5 and $3.0 \mathrm{t} \mathrm{ha}^{-1}$, respectively),

- B2/P4 (fertilised with biochar and ash at doses of 11.5 and $4.5 \mathrm{t} \mathrm{ha}^{-1}$, respectively).

\subsection{Biochar and Biomass Ash}

Tables 1 and 2 present the results of the $\mathrm{pH}$ value, total carbon and total nitrogen content, ash and water content, volatile substances and contents of available forms of the chosen minerals in biochar and biomass ash used as fertilisers.

Table 1. $\mathrm{pH}$ value, contents of absorbable forms of macroelements and percentage content of carbon and nitrogen in biochar and ash from biomass.

\begin{tabular}{|c|c|c|c|c|c|c|}
\hline & \multirow{3}{*}{$\mathrm{pH}(\mathrm{KCl})$} & Carbon & Nitrogen & $\mathbf{P}_{2} \mathrm{O}_{5}$ & $\mathrm{~K}_{2} \mathrm{O}$ & Mg \\
\hline & & \multicolumn{2}{|c|}{$\%$} & \multicolumn{3}{|c|}{$\mathrm{mg} \mathrm{kg}^{-1}$} \\
\hline & & & & $\mathrm{x} \pm \mathrm{SD}$ & & \\
\hline Biochar & $6.59 \pm 0.21$ & $74.35 \pm 0.24$ & $0.93 \pm 0.07$ & $1382 \pm 41$ & $5752 \pm 63$ & $645 \pm 22$ \\
\hline Ash & $12.89 \pm 0.32$ & $1.22 \pm 0.22$ & $0.17 \pm 0.01$ & $6394 \pm 52$ & $91133 \pm 4$ & $31306 \pm 74$ \\
\hline
\end{tabular}

Table 2. Contents of water, ash and volatile substances in biochar and ash from biomass.

\begin{tabular}{cccc}
\hline & Water & Ash & Volatile Substances \\
\cline { 2 - 4 } & \multicolumn{3}{c}{$\mathbf{~} \mathbf{x} \pm$ SD } \\
\hline Biochar & $9.11 \pm 0.03$ & $11.57 \pm 0.21$ & $66.42 \pm 0.18$ \\
\hline Ash & - & - & $94.42 \pm 0.27$ \\
\hline \multicolumn{4}{c}{ x-average, SD—standard deviation. }
\end{tabular}

Table 3 presents the contents of selected macro- and microelements in biochar and ash from biomass. Ash from biomass was characterised by a higher content of all the ingredients studied than that found in biochar. Bearing in mind that fertilisers used in agriculture may contain toxic metals, the fertiliser material applied was examined. Aluminium, arsenic, cadmium and lead were not present in the materials analysed. 
Table 3. Contents of selected macro- and microelements in biochar and ash from biomass.

\begin{tabular}{|c|c|c|c|c|c|c|c|}
\hline & Al & As & $\mathrm{Ca}$ & $\mathrm{Cd}$ & $\mathrm{Cr}$ & $\mathrm{Cu}$ & Mn \\
\hline & \multicolumn{7}{|c|}{$\mathrm{mg} \mathrm{kg}^{-1}$} \\
\hline & \multicolumn{7}{|c|}{$x \pm S D$} \\
\hline Biochar & $<0.01$ & $<0.01$ & $18,520 \pm 21$ & $<0.01$ & $<0.01$ & $10 \pm 0.8$ & $240 \pm 2.5$ \\
\hline \multirow[t]{4}{*}{ Ash } & $<0.01$ & $<0.01$ & $131,220 \pm 35$ & $<0.01$ & $50 \pm 0.9$ & $110 \pm 0.7$ & $1930 \pm 9.5$ \\
\hline & Mo & $\mathrm{Na}$ & $\mathrm{Ni}$ & $\mathrm{Pb}$ & $S$ & $\mathrm{Sr}$ & $\mathrm{Zn}$ \\
\hline & \multicolumn{7}{|c|}{$\mathrm{mg} \mathrm{kg}^{-1}$} \\
\hline & \multicolumn{7}{|c|}{$x \pm S D$} \\
\hline Biochar & $<0.01$ & $<0.01$ & $<0.01$ & $<0.01$ & $880 \pm 12$ & $<0.01$ & $130 \pm 11.5$ \\
\hline Ash & $<0.01$ & $<0.01$ & $40 \pm 2.5$ & $<0.01$ & $19,710 \pm 23$ & $<0.01$ & $710 \pm 8.2$ \\
\hline
\end{tabular}

\subsection{Soil}

Figure 1 shows the $\mathrm{pH}$ value of the soil before the experiment (2015) and after the first and second year of cultivation, depending on the fertiliser used. The soil taken from the area on which the field experiment was carried out was, as in the previous experiment, characterised by an acid reaction ( $\mathrm{pH}$ in $1 \mathrm{M} \mathrm{KCl}$-4.98). The $\mathrm{pH}$ value of the soil determined for the control plots (no fertilisation) was 5.13, after both the first and second year of cultivation. There were no statistically significant differences for this variant when compared to the results obtained prior to the experiment. The addition of biochar, ash and their mixture in the soil influenced the increase in the $\mathrm{pH}$ value of the soil to a statistically significant extent when compared to the results obtained in 2015 (in 13 cases out of the 16 analysed). Depending on the type of fertiliser used and its application rate, there was an increase in the study parameter by a value in the range from 0.19 to 1.29 after the first year and from 0.04 to 1.13 after the second year of cultivation when compared to the control group. The highest concentrations of hydrogen ions in the soil, after both the first and second year of cultivation of giant miscanthus were determined in the case of fertilisation with ash at an application rate of $4.5 \mathrm{tha}^{-1}$ and a combination of biochar and ash at an application rate of 3.0 and $4.5 \mathrm{tha}^{-1}$.

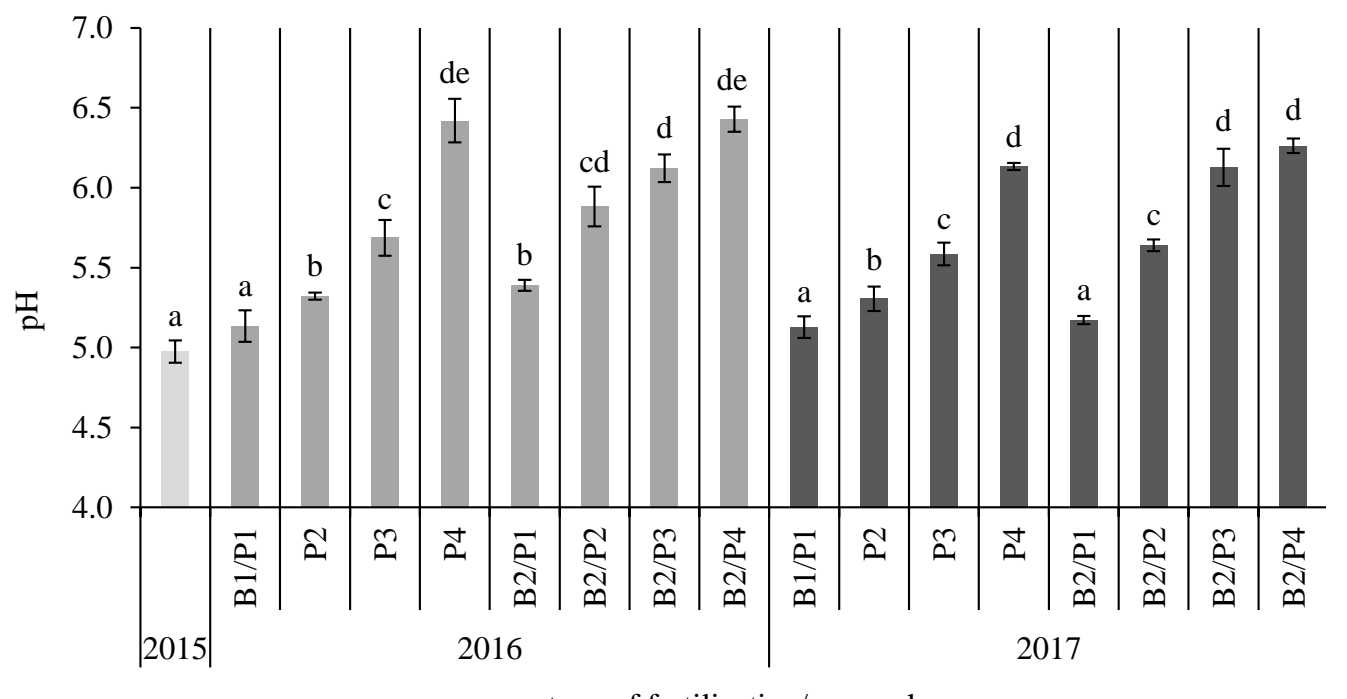

type of fertilization/ research year

Figure 1. $\mathrm{pH}$ value of the soil before the experiment (2015) and after the first and second year of cultivation, depending on the fertiliser used. Differences between average values marked with the same Arabic letters are not statistically significant at the level of $\alpha \leq 0.05$ according to the Bonferroni test. 
Figure 2 presents the contents of absorbable forms of phosphorus, potassium and magnesium in the soil before the experiment (2015) and after the first and second year of cultivation, depending on the fertilisers used. The analyses performed before the field experiment showed the contents of absorbable forms of phosphorus, potassium and magnesium in the soil at a level of 48, 90 and $95 \mathrm{mg}$ $\mathrm{kg}^{-1}$ respectively. The contents of the study elements in the fertiliser variants showed, in most cases, statistically significant differences in comparison with the control plots and the year 2015 (before the experiment). After the second year of cultivation of giant miscanthus (2017), the contents of the form of phosphorus, potassium and magnesium available to plants in the soil on plots without the use of fertilisers amounted to $58.75,104.00$ and $95.25 \mathrm{mg} \mathrm{kg}^{-1}$, respectively. Thus, a slight decrease in the potassium content and an increase in the content of phosphorus and magnesium was noted in relation to the previous season.

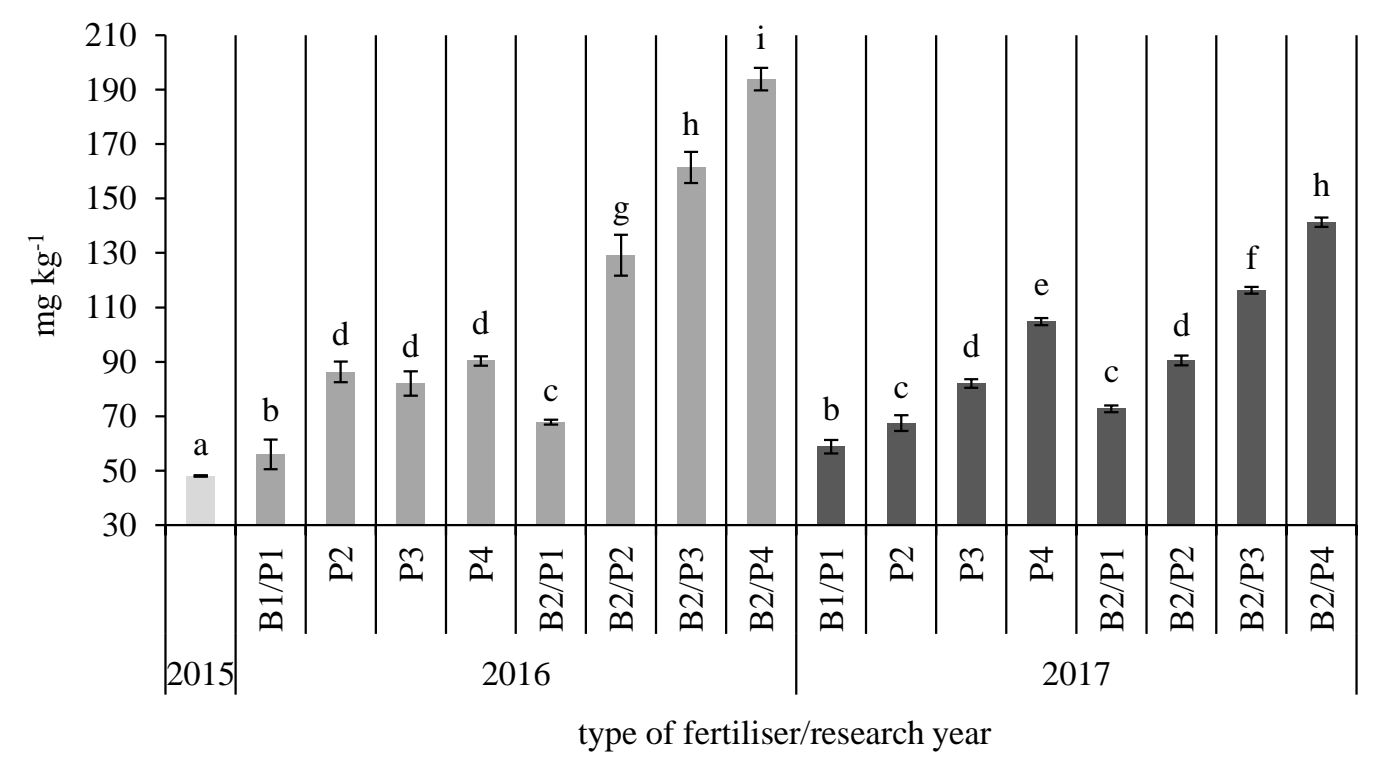

(a)

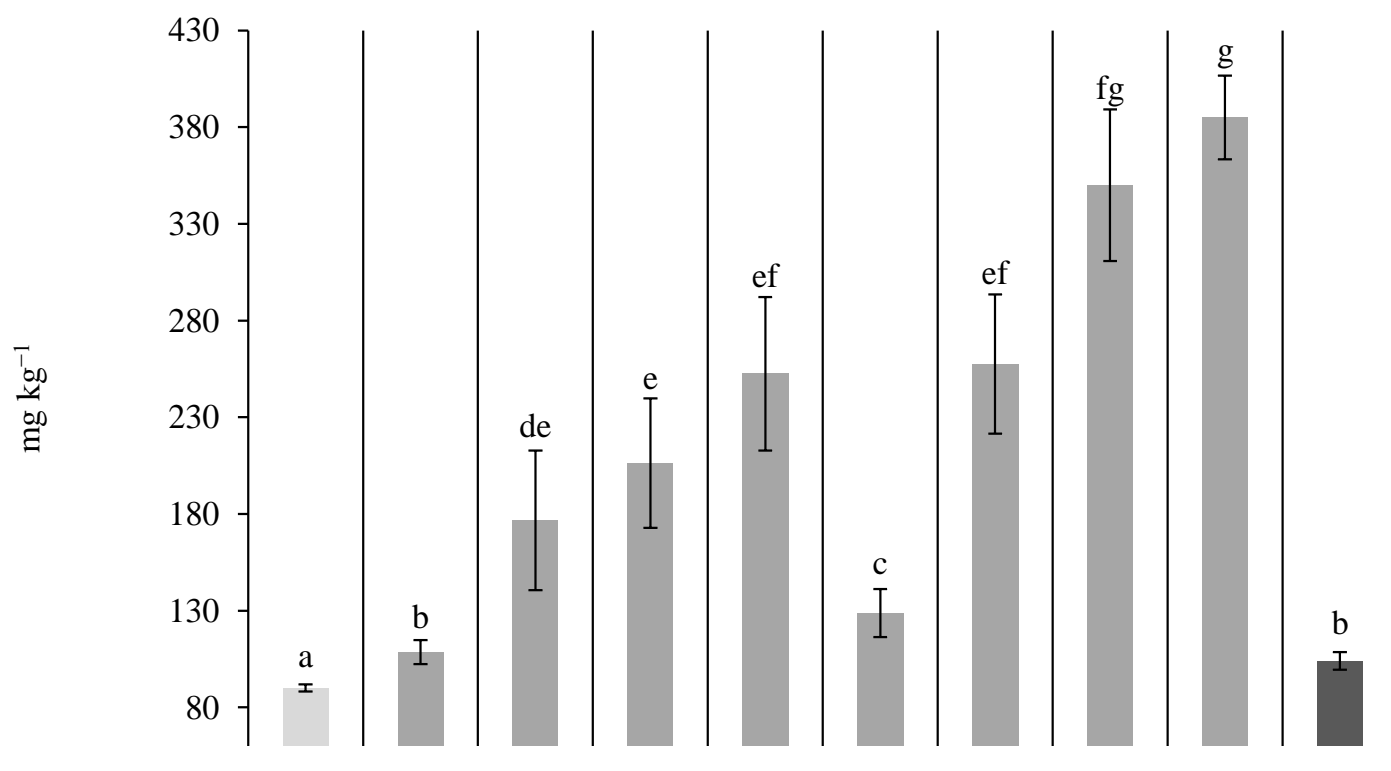

(b)

Figure 2. Cont. 


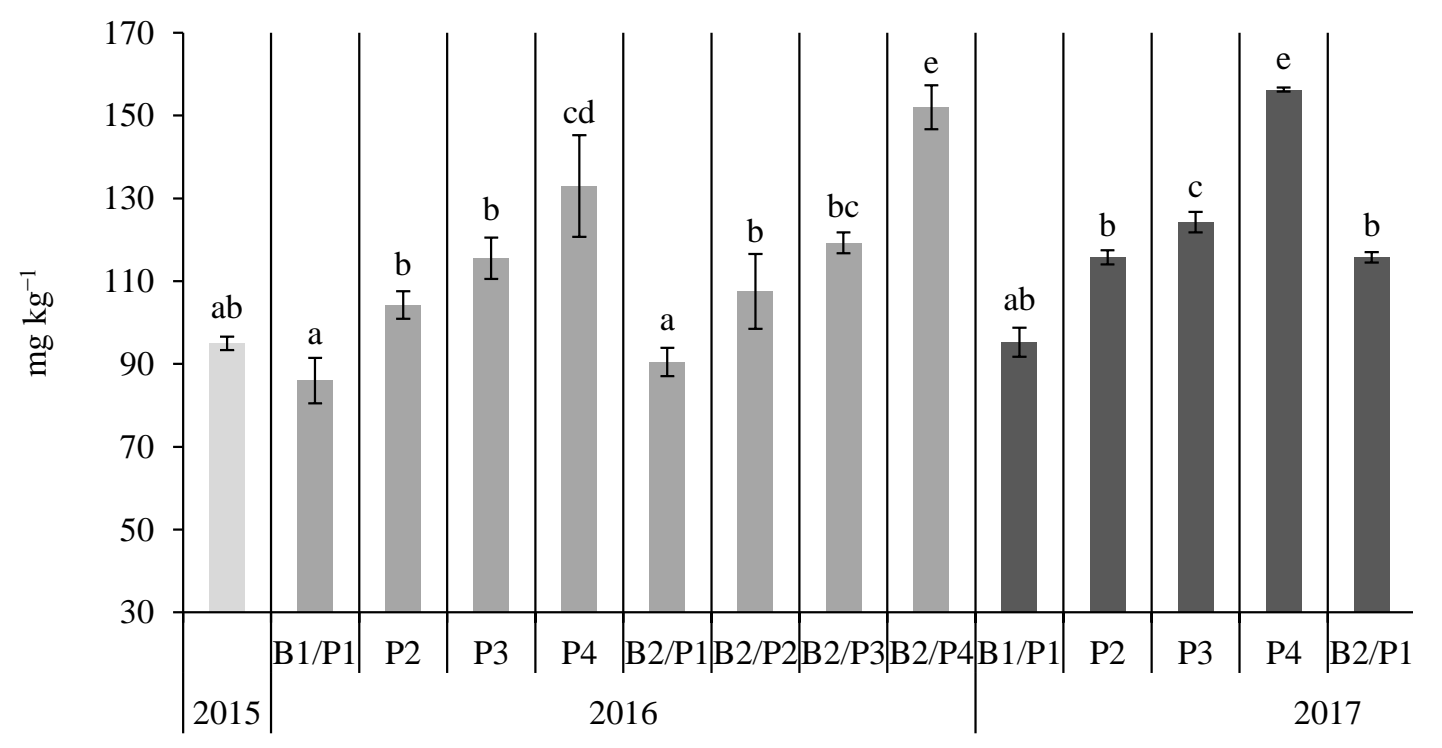

(c)

Figure 2. Contents of absorbable forms of phosphorus $\mathrm{P}_{2} \mathrm{O}_{5}(\mathbf{a})$, potassium $\mathrm{K}_{2} \mathrm{O}(\mathbf{b})$, and magnesium $\mathrm{Mg}$ (c) in the soil before the experiment (2015) and after the first and second year of cultivation, depending on the fertiliser used. Differences between average values marked with the same Arabic letters are not statistically significant at the level of $\alpha \leq 0.05$ according to the Bonferroni test.

Figure 3 presents the percentage of total carbon and total nitrogen before the experiment (2015) and after the first and second year of cultivation, depending on the fertiliser used. The content of carbon in the soil in the area selected for the field experiment was $0.64 \%$. After the first year of cultivation of giant miscanthus (2016), an increase of 3.13\% (control plots) was noted in the carbon content in the soil. In 2017, this content increased to 3.17\%; however, it was not a statistically significant change. The experimental factors in the form of fertilisation with ash did not significantly change this parameter in relation to the control plots after the first and second year of cultivation. Only fertilising with biochar and the combination of biochar with ash contributed to an increase in the concentration of total carbon in the soil when compared to the control plots. The highest carbon content determined in the soil samples collected was $4.41 \%$ after the first year and $4.34 \%$ after the second year of the experiment.

The content of carbon in the soil before the experiment was $0.63 \%$ and it increased to $1.16 \%$ after the first year of cultivation (control plots). In 2017, there was a statistically insignificant decrease in the content of this parameter to the value of $1.06 \%$. The fertilisers used in the experiment did not have a significant impact on the change in the carbon content when compared to the control plots after the first year of cultivation (carbon content in the range from 1.15 to 1.27\%). After the second year, small fluctuations in these parameters were noted; however, in most cases they were not statistically significant. The carbon content in the soil, after the use of fertilisers, was in the range 1.13-1.26\%.

The content of nitrogen in the arable land studied was $0.26 \%$ before the field experiment. The content of this element in the control plots dropped to $0.02 \%$ and $0.07 \%$, respectively, after the first and second year of cultivation. The concentration of nitrogen in the soil, after the use of fertilisers, was in the range $0.002-0.07 \%$ after the second year of the experiment. The following was observed. 


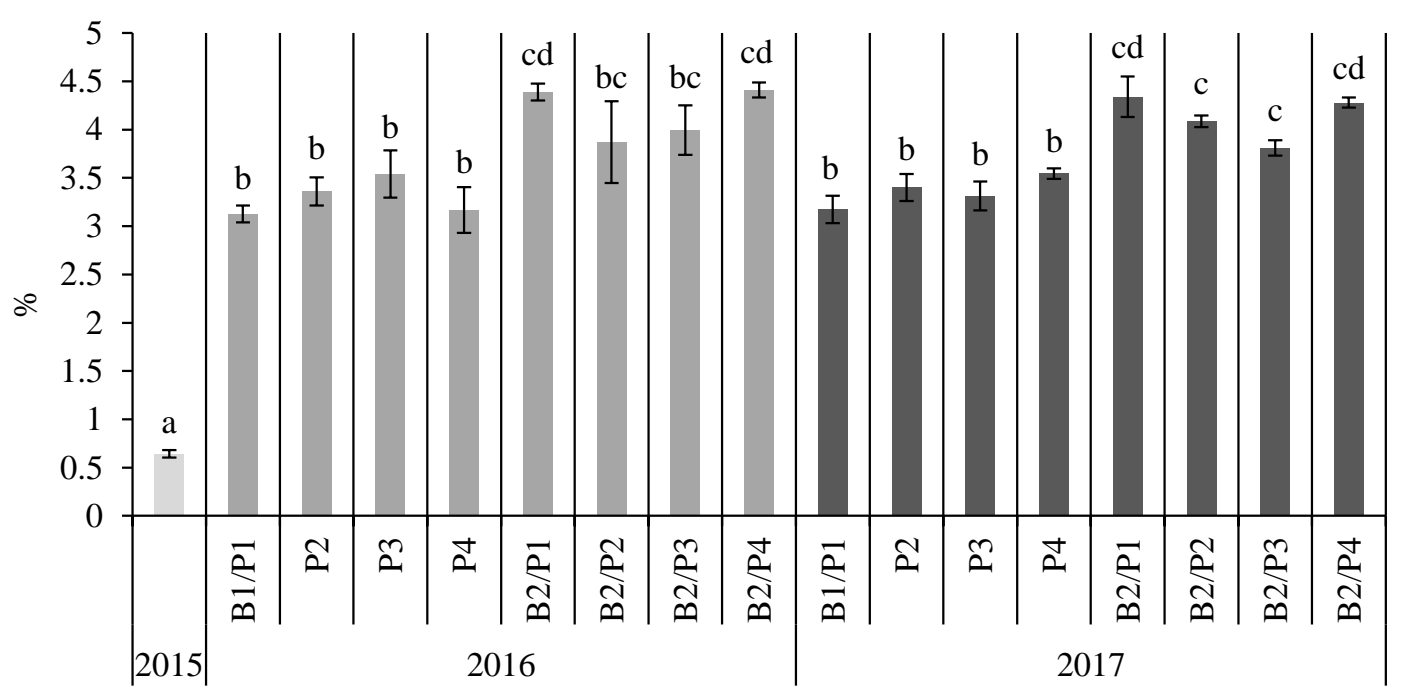

type of fertiliser/research year

(a)

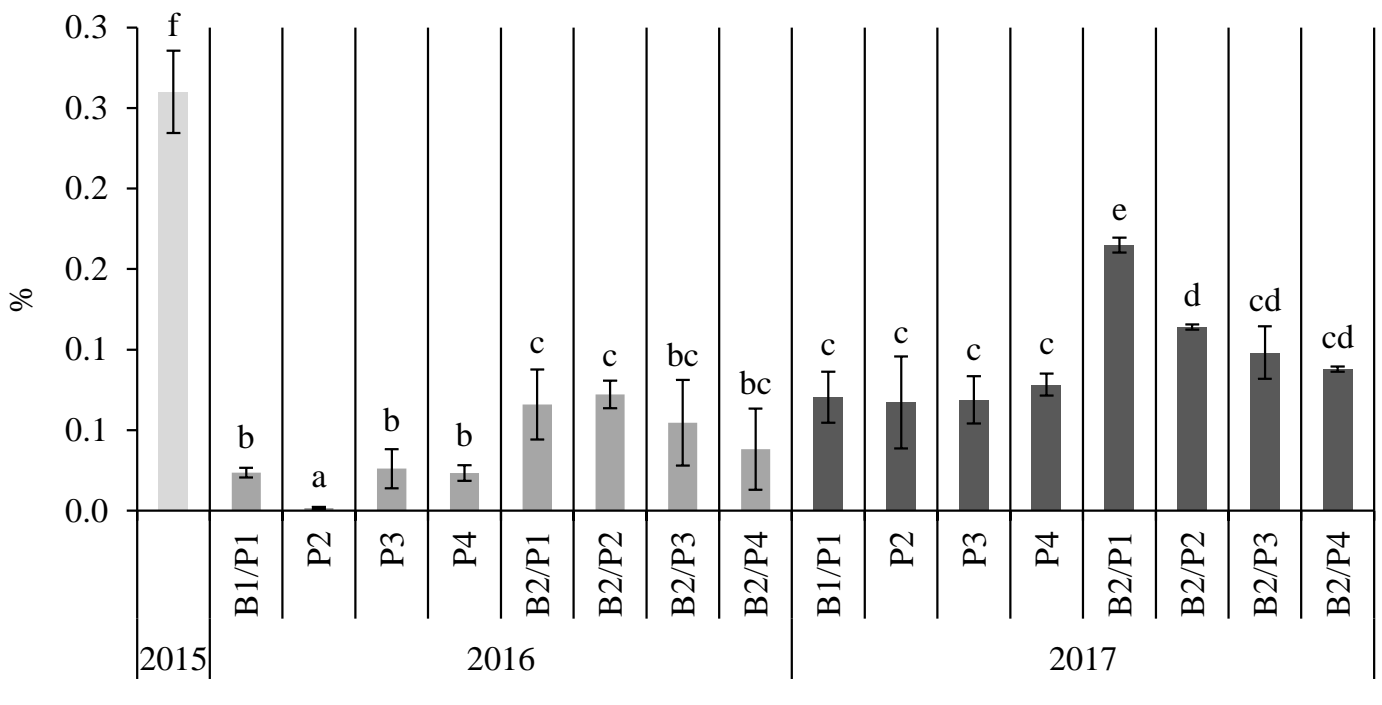

type of fertiliser/research year

(b)

Figure 3. Content of carbon (a) and nitrogen (b) in the soil before the experiment (2015) and after the first and second year of cultivation, depending on the fertiliser used. Differences between average values marked with the same Arabic letters are not statistically significant at the level of $\alpha \leq 0.05$ according to the Bonferroni test.

Table 4 presents the total contents of selected macro- and microelements and heavy metals in the soil before the experiment (2015) and after the first and second year of cultivation, depending on the fertiliser used. The highest concentration of the macroelements examined (total contents of calcium, sodium and sulphur) in both 2016 and 2017 was recorded after the use of fertiliser in the form of a combination of biochar and ash at an application rate of $1.5 \mathrm{t} \mathrm{ha}^{-1}$. The largest increase in the totals of the soil macroelements examined after the first and second year of the experiment when compared to the year 2015 was 50\% and 31\%, respectively. The lowest total contents of Ca, Na and S in 2016 and 2017 were recorded in the case of fertilising with ash (all fertiliser application rates). 
Table 4. Contents of selected macro- and microelements and heavy metals in the soil before the experiment and after the first and second year of cultivation, depending on the fertiliser used.

\begin{tabular}{|c|c|c|c|c|c|c|c|c|c|c|c|}
\hline \multirow{4}{*}{ હ્ર } & \multirow{4}{*}{ 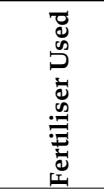 } & \multicolumn{10}{|c|}{ Macro- and Microelements } \\
\hline & & As & $\mathrm{Ca}$ & $\mathrm{Cd}$ & $\mathrm{Cu}$ & Mn & $\mathrm{Na}$ & $\mathbf{N i}$ & $\mathrm{Pb}$ & $\mathrm{S}$ & $\mathrm{Zn}$ \\
\hline & & \multicolumn{10}{|c|}{$\mathrm{mg} \mathrm{kg}^{-1}$} \\
\hline & & \multicolumn{10}{|c|}{$\mathrm{x} \pm \mathrm{SD}$} \\
\hline$\stackrel{n}{\stackrel{n}{N}}$ & - & $<0.01$ & $2300^{\mathrm{b}} \pm 19$ & $<0.01$ & $20.00^{\mathrm{a}} \pm 0.41$ & $624^{c} \pm 5$ & $174.75^{\mathrm{h}} \pm 1.50$ & $<0.01$ & $12.40^{\mathrm{a}} \pm 0.41$ & $113^{\mathrm{a}} \pm 0.87$ & $50.03^{d} \pm 2.41$ \\
\hline \multirow{8}{*}{ 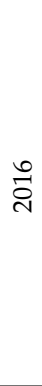 } & $\mathrm{B} 1 / \mathrm{P} 1$ & $<0.01$ & $2646^{c} \pm 19$ & $<0.01$ & $53.75^{c} \pm 0.50$ & $520^{b} \pm 18$ & $91.09^{\mathrm{e}} \pm 26.25$ & $<0.01$ & $13.91^{\mathrm{b}} \pm 0.69$ & $160^{c} \pm 13$ & $25.95^{a} \pm 10.70$ \\
\hline & P2 & $<0.01$ & $2352^{b} \pm 158$ & $<0.01$ & $50.93^{c} \pm 1.57$ & $505^{b} \pm 2$ & $93.88^{\mathrm{e}} \pm 40.23$ & $<0.01$ & $13.65^{b} \pm 0.82$ & $131^{\mathrm{c}} \pm 18$ & $30.49^{\mathrm{ab}} \pm 12.37$ \\
\hline & P3 & $<0.01$ & $2338^{\mathrm{b}} \pm 20$ & $<0.01$ & $46.32^{b} \pm 3.12$ & $507^{b} \pm 27$ & $19.17^{\mathrm{a}} \pm 8.47$ & $<0.01$ & $13.89^{\mathrm{b}} \pm 0.22$ & $139^{c} \pm 19$ & $25.49^{a} \pm 10.24$ \\
\hline & $\mathrm{P} 4$ & $<0.01$ & $2436^{\mathrm{bc}} \pm 93$ & $<0.01$ & $51.54^{\mathrm{c}} \pm 2.44$ & $527^{b} \pm 12$ & $11.48^{\mathrm{a}} \pm 0.85$ & $<0.01$ & $16.10^{\mathrm{e}} \pm 0.60$ & $125^{b} \pm 3$ & $33.72^{b} \pm 4.80$ \\
\hline & $\mathrm{B} 2 / \mathrm{P} 1$ & $<0.01$ & $2848^{c} \pm 139$ & $<0.01$ & $53.97^{c} \pm 2.17$ & $505^{b} \pm 11$ & $109.59^{\mathrm{f}} \pm 18.75$ & $<0.01$ & $13.70^{c} \pm 0.82$ & $196^{\mathrm{e}} \pm 6$ & $37.07^{b} \pm 3.30$ \\
\hline & $\mathrm{B} 2 / \mathrm{P} 2$ & $<0.01$ & $3690^{\mathrm{f}} \pm 350$ & $<0.01$ & $54.78^{\mathrm{c}} \pm 0.66$ & $516^{\mathrm{b}} \pm 2$ & $125.25^{\mathrm{g}} \pm 4.70$ & $<0.01$ & $16.97^{\mathrm{e}} \pm 0.73$ & $210^{\mathrm{f}} \pm 6$ & $56.99^{d} \pm 10.02$ \\
\hline & $\mathrm{B} 2 / \mathrm{P} 3$ & $<0.01$ & $2893^{c} \pm 150$ & $<0.01$ & $44.89^{b} \pm 3.40$ & $484^{\mathrm{a}} \pm 3$ & $51.71^{\mathrm{c}} \pm 20.58$ & $<0.01$ & $13.60^{\mathrm{c}} \pm 0.84$ & $197^{\mathrm{e}} \pm 2$ & $26.67^{a} \pm 10.23$ \\
\hline & $\mathrm{B} 2 / \mathrm{P} 4$ & $<0.01$ & $3038^{d} \pm 65$ & $<0.01$ & $47.15^{b} \pm 3.55$ & $521^{b} \pm 5$ & $79.68^{d} \pm 25.23$ & $<0.01$ & $15.29^{d} \pm 0.78$ & $213^{f} \pm 8$ & $44.69^{c} \pm 0.81$ \\
\hline \multirow{8}{*}{ ڤิ) } & $\mathrm{B} 1 / \mathrm{P} 1$ & $<0.01$ & $1959^{a} \pm 7$ & $<0.01$ & $42.55^{b} \pm 0.96$ & $460^{\mathrm{a}} \pm 5$ & $33.60^{\mathrm{b}} \pm 1.82$ & $<0.01$ & $13.24^{b} \pm 0.38$ & $154^{c} \pm 5$ & $25.51^{\mathrm{a}} \pm 0.76$ \\
\hline & P2 & $<0.01$ & $2303^{b} \pm 105$ & $<0.01$ & $47.89^{b} \pm 1.10$ & $478^{\mathrm{a}} \pm 4$ & $52.93^{c} \pm 6.01$ & $<0.01$ & $13.26^{\mathrm{c}} \pm 0.15$ & $169^{\mathrm{cd}} \pm 2$ & $27.67^{\mathrm{a}} \pm 0.27$ \\
\hline & P3 & $<0.01$ & $2137^{b} \pm 138$ & $<0.01$ & $44.63^{b} \pm 3.50$ & $453^{a} \pm 6$ & $52.66^{c} \pm 37.08$ & $<0.01$ & $13.89^{b} \pm 0.42$ & $173^{d} \pm 7$ & $27.26^{\mathrm{a}} \pm 0.21$ \\
\hline & $\mathrm{P} 4$ & $<0.01$ & $3303^{e} \pm 858$ & $<0.01$ & $57.96^{\mathrm{d}} \pm 3.77$ & $495^{\mathrm{ab}} \pm 12$ & $158.34^{g} \pm 35.16$ & $<0.01$ & $15.97^{\mathrm{d}} \pm 0.93$ & $189^{\mathrm{d}} \pm 10$ & $34.33^{\mathrm{b}} \pm 1.95$ \\
\hline & $\mathrm{B} 2 / \mathrm{P} 1$ & $<0.01$ & $2306^{b} \pm 33$ & $<0.01$ & $44.61^{\mathrm{b}} \pm 1.61$ & $481^{\mathrm{a}} \pm 8$ & $55.21^{\mathrm{c}} \pm 1.96$ & $<0.01$ & $15.05^{\mathrm{c}} \pm 0.11$ & $190^{\mathrm{d}} \pm 4$ & $29.27^{\mathrm{ab}} \pm 0.39$ \\
\hline & $\mathrm{B} 2 / \mathrm{P} 2$ & $<0.01$ & $3137^{\mathrm{d}} \pm 297$ & $<0.01$ & $57.80^{\mathrm{d}} \pm 2.28$ & $511^{b} \pm 17$ & $184.87^{\mathrm{h}} \pm 37.12$ & $<0.01$ & $13.63^{c} \pm 0.50$ & $189^{\mathrm{d}} \pm 4$ & $32.23^{b} \pm 1.47$ \\
\hline & $\mathrm{B} 2 / \mathrm{P} 3$ & $<0.01$ & $2684^{c} \pm 167$ & $<0.01$ & $51.37^{c} \pm 2.67$ & $505^{b} \pm 8$ & $82.10^{\mathrm{d}} \pm 13.84$ & $<0.01$ & $15.29^{\mathrm{d}} \pm 0.74$ & $187^{d} \pm 5$ & $33.32^{b} \pm 2.08$ \\
\hline & $\mathrm{B} 2 / \mathrm{P} 4$ & $<0.01$ & $2747^{c} \pm 48$ & $<0.01$ & $48.65^{b} \pm 0.20$ & $535^{b} \pm 17$ & $48.89^{c} \pm 4.07$ & $<0.01$ & $16.94^{\mathrm{e}} \pm 0.57$ & $199^{\mathrm{e}} \pm 9$ & $35.03^{b} \pm 1.19$ \\
\hline
\end{tabular}

$\mathrm{x}$-average, SD—standard deviation. Differences between average values marked with the same Arabic letters (a-f) are not statistically significant at the level of $\alpha \leq 0.05$ according to the Bonferroni test. 
The highest total contents recorded for the microelements examined in soil samples collected after the first and second year of cultivation of giant miscanthus, respectively, were found in plots that were fertilised with biochar and biochar with ash at an application rate of $4.5 \mathrm{tha}^{-1}$. The decrease in the totals of the soil microelements after the first and second year of the experiment was determined to be $15 \%$ and $13 \%$, respectively, in comparison with the initial values obtained, i.e., before the experiment was carried out for all the aforementioned variants of fertiliser dosage. The lowest total value found during analysis of microelements in the soil in 2016 and 2017 was recorded in the case of fertilising with biochar and ash at an application rate of $3.0 \mathrm{t} \mathrm{ha}^{-1}$ and ash alone at this application rate. In the soil samples studied, no arsenic, cadmium or nickel was found in the material collected before the experiment or after the first and second year of the experiment-values were below the detection limit $\left(0.01 \mathrm{mg} \mathrm{kg}^{-1}\right)$ of the analytical method used. The marked concentration of lead changed slightly depending on factors and the year of research, but it should be emphasised that, again, in no case did it exceed the permissible contents for soil used for agricultural purposes.

Principal component analysis of variables (elements) for the soil after the first and second year of cultivation of giant miscanthus identified two factors describing the level of variation in the group with values for the first year for factor $1(70 \%)$ and factor $2(18.7 \%)$, as well as for the second year for factor $1(46.6 \%)$ and factor $2(24.4 \%)$, respectively. The selection of the number of main components was made using the scree test and the Kaiser criterion. The first factor included the following variables: calcium, copper, manganese, sodium, lead, sulphur, zinc (first year) and calcium, sodium, sulphur, zinc (second year). The second factor was represented by the following variables: sodium (first year), and copper and manganese (second year). It was noted that factor 1 is most strongly associated with the variable $\mathrm{Ca}$, while factor 2 with the variable $\mathrm{Mn}$ (first year). In the second year of research it was found that factor 1 is mainly associated with the variable $\mathrm{Zn}$, while factor 2 is most strongly associated with the variable Na. The projection of variables on the factor plane is presented in Figure 4.

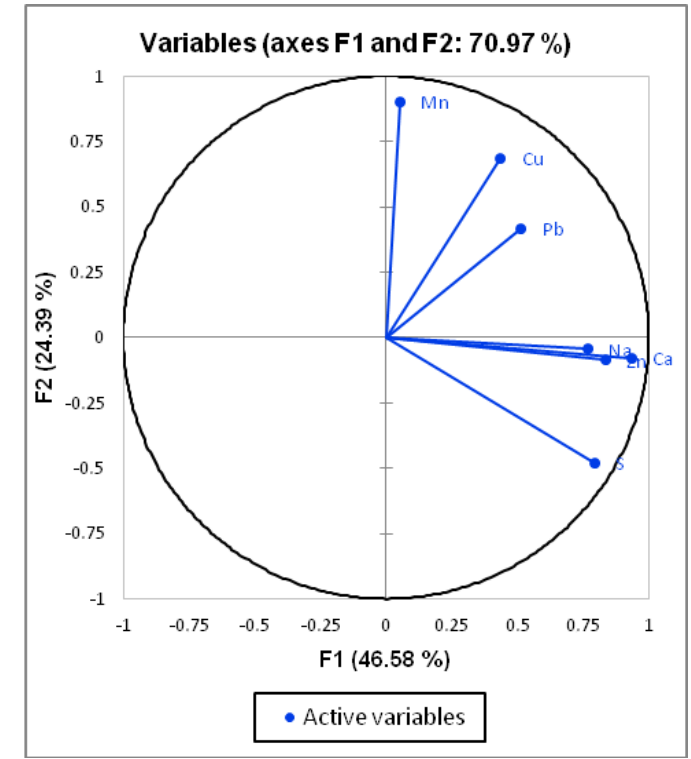

(a)

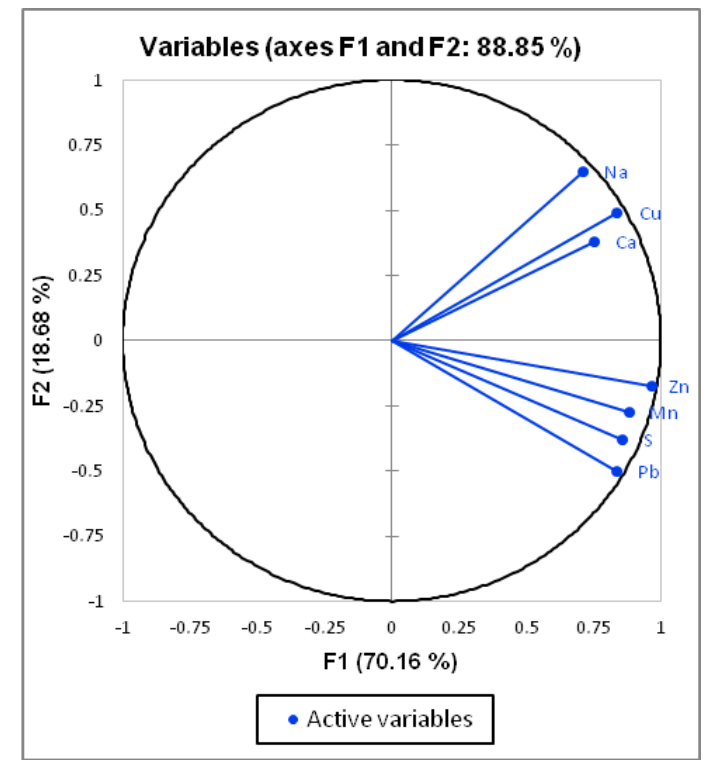

(b)

Figure 4. Variable plot in the system of the first two factor axes for the soil after the first (a) and second (b) year of cultivation of giant miscanthus.

\subsection{Biomass of Giant Miscanthus}

Figure 5 presents the yield of biomass of giant miscanthus (dry matter-d.m.) after the first year of cultivation, depending on the fertiliser used. The average yield of biomass obtained from the control plots (no fertiliser) was $1.04 \mathrm{t} \mathrm{ha}^{-1}$ of d.m. The largest values of the parameter studied of 1.22, 1.22 and $1.75 \mathrm{tha}^{-1}$, respectively, were recorded in the case of fertilising with ash at an application 
rate of $1.5 \mathrm{tha}^{-1}$, with biochar and with the combination of biochar and ash at an application rate of $1.5 \mathrm{tha}^{-1}$. The highest yield of biomass of plants in 2016 was obtained by introducing the fertilisation factor in the form of the combination of biochar and ash at an application rate of $1.5 \mathrm{tha}^{-1}$. Fertilisation with ash at doses of 3.0 and $4.5 \mathrm{tha}^{-1}$ and its combinations with biochar affected yield, with values of $0.75,0.57,0.90$ and $0.86 \mathrm{tha}^{-1}$ of d.m., respectively.

After the second year of cultivation of giant miscanthus, the average yield of biomass in the control plots was $8.82 \mathrm{t} \mathrm{ha}^{-1}$ of d.m. As in the previous year, the highest values of average yield of dry matter of 9.50, 13.04, and $9.80 \mathrm{tha}^{-1}$, respectively, were recorded for the plots fertilised with the lowest application rate of ash, biochar alone, and the combination of biochar and ash at a dose of $1.5 \mathrm{tha} \mathrm{t}^{-1}$. The highest yield of dry matter of plants in 2017 was recorded on plots fertilised only with biochar before the experiment. Fertiliser application rates of ash of 3.0 and $4.5 \mathrm{tha}^{-1}$ and its combination with biochar negatively influenced crop yield - there was a decrease in the average yield of dry matter of plants when compared with the control plots of $1.43,2.56,0.23$, and $0.38 \mathrm{t} \mathrm{ha}^{-1}$, respectively (Figure 5).

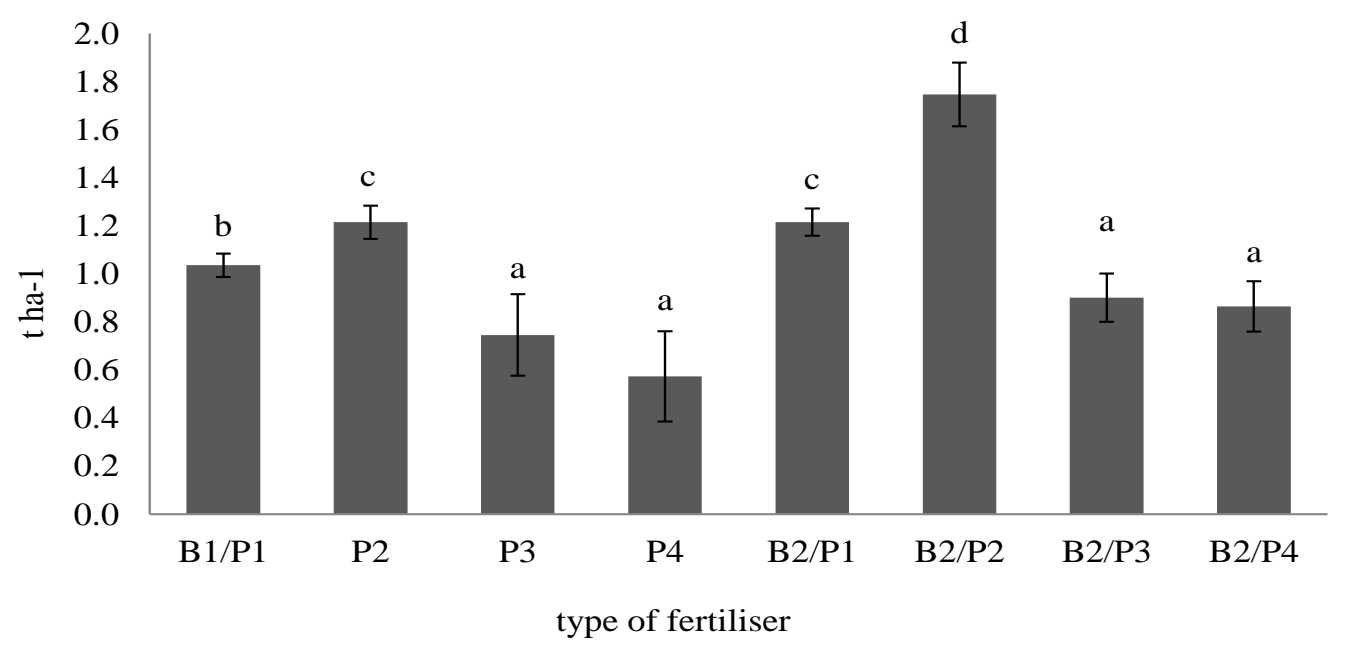

(a)

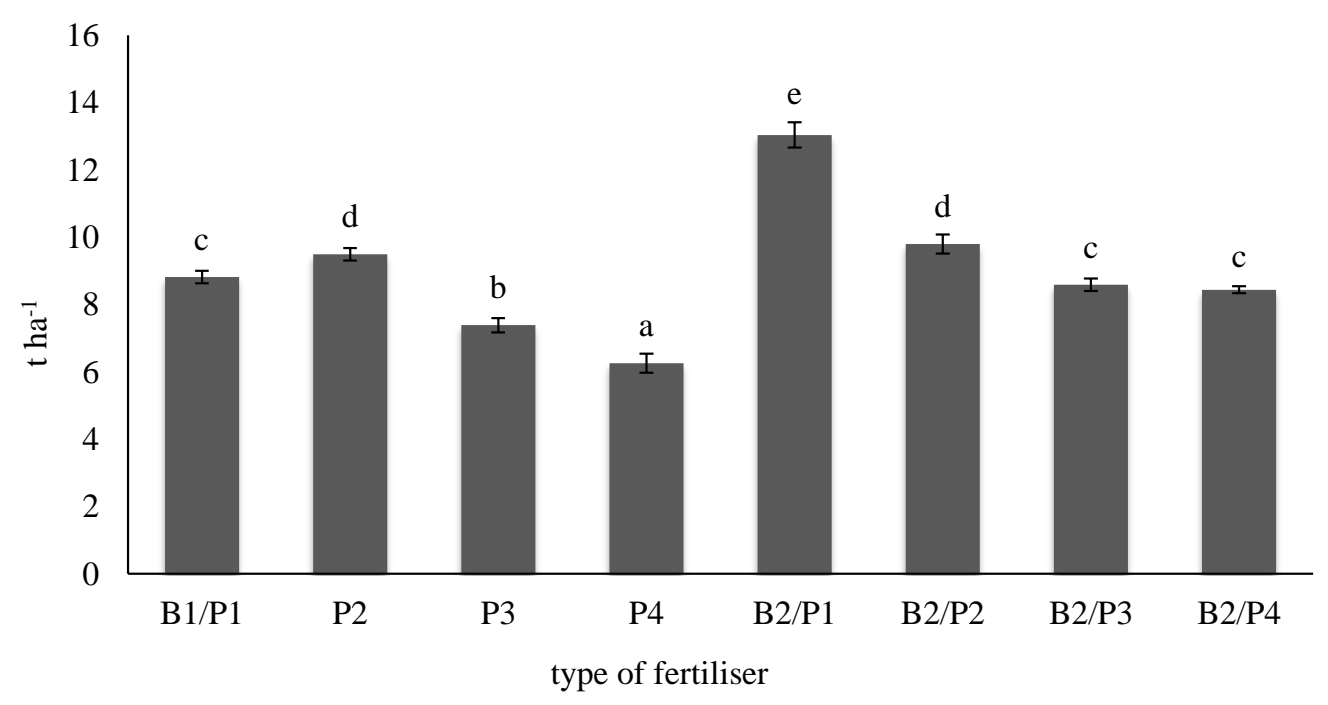

(b)

Figure 5. Biomass yield of giant miscanthus after the first (a) and second (b) year of cultivation, depending on the fertilisation used. Differences between average values marked with the same Arabic letters are not statistically significant at the level of $\alpha \leq 0.05$ according to the Bonferroni test. 
Figure 6 presents the calorific value of biomass of giant miscanthus, depending on the fertiliser used and the year of research. The calorific value of biomass after the first year of cultivation ranged from 17.54 to $17.75 \mathrm{MJ} \mathrm{kg}^{-1}$ of d.m., while after the second year of cultivation it ranged from 17.65 to $17.72 \mathrm{MJ} \mathrm{kg}^{-1}$ of d.m. There were no statistically significant differences between the values measured. When assessing the calorific value of the biomass of giant miscanthus in laboratory tests, both after the first and second year of cultivation, no effects were found on changes in the parameters analysed in relation to the use of fertilisers.

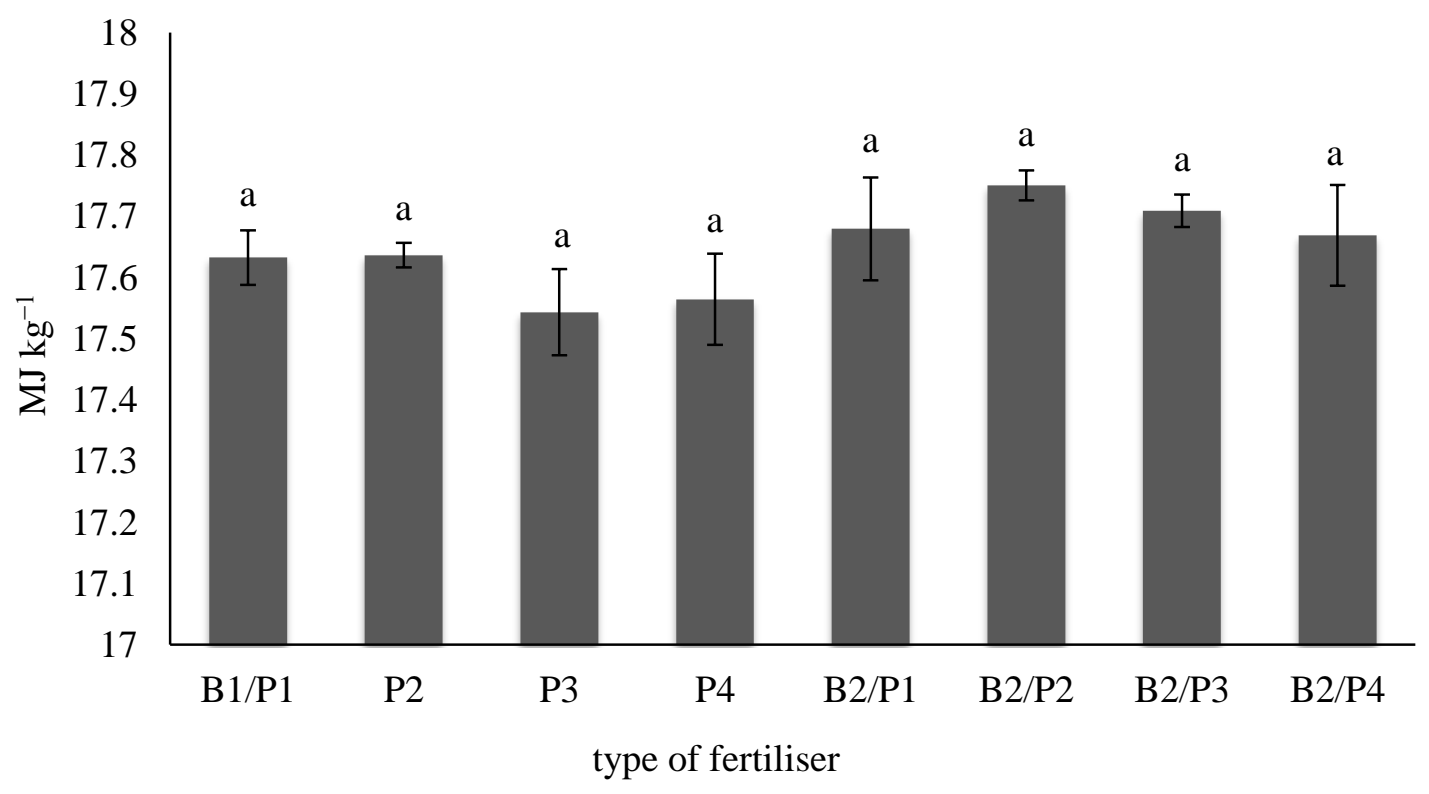

(a)

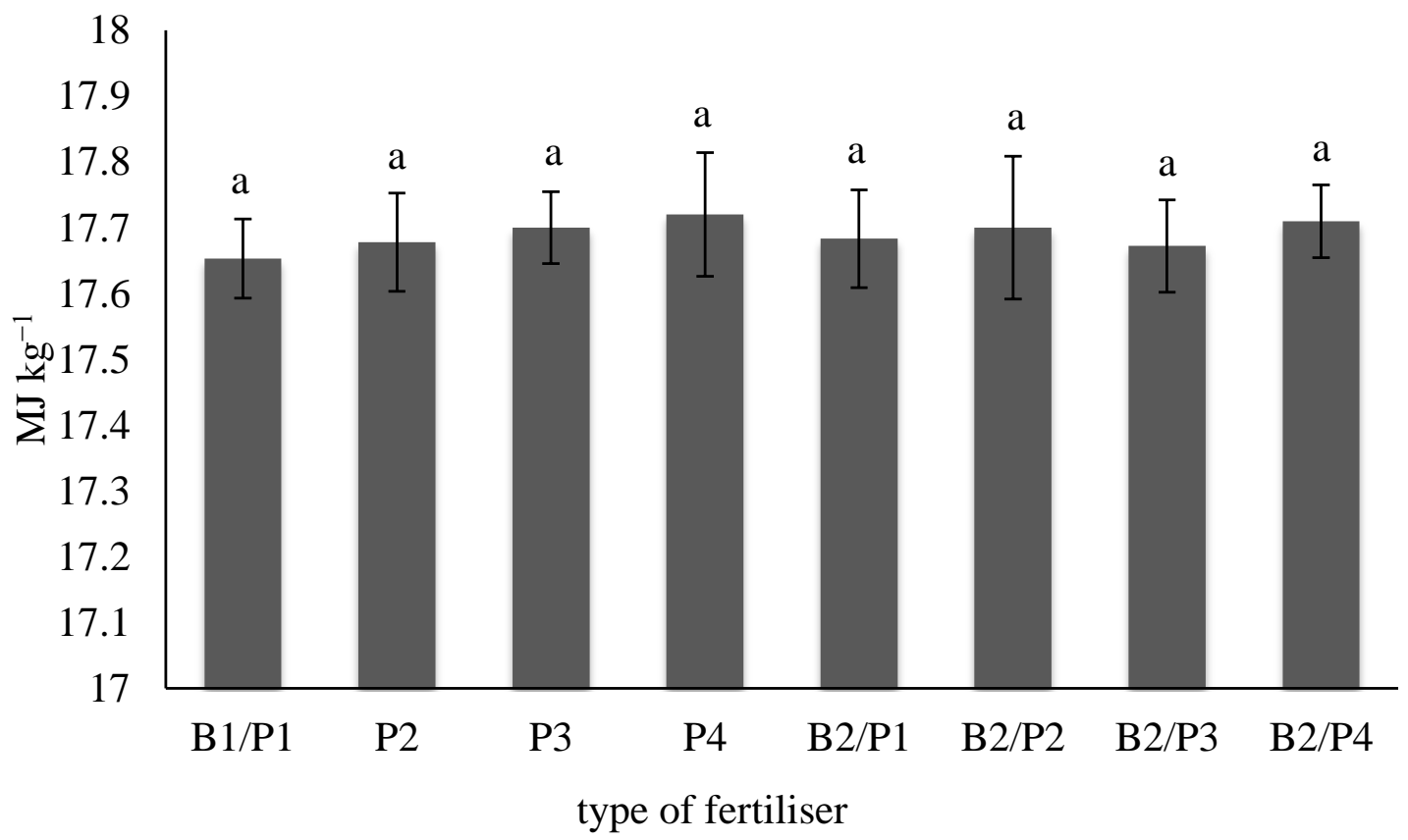

(b)

Figure 6. Calorific value of giant miscanthus after the first (a) and second (b) year of cultivation, depending on the fertiliser used. Differences between average values marked with the same Arabic letters are not statistically significant at the level of $\alpha \leq 0.05$ according to the Bonferroni test. 
Table 5 presents the total contents of selected macroelements in the biomass of giant miscanthus, depending on the fertiliser used and year of research. The highest concentration of the macroelements studied in the above ground parts of plants in 2016 and 2017, respectively, was recorded after the use of fertiliser in the form of ash at the lowest application rate and ash at an application rate of $3.0 \mathrm{t} \mathrm{ha}^{-1}$. The greatest increase in the total of the macroelements studied in the biomass of plants was recorded after the first and second year of the experiment in the control plots, with increases of $13 \%$ and 7\%, respectively. The lowest total content of the elements studied in 2016 and 2017, respectively, was recorded for the fertiliser in the form of biochar and the combination of biochar and ash at a dose of $1.5 \mathrm{t} \mathrm{ha}^{-1}$. Among the ions analysed, the highest concentration in the biomass of giant miscanthus was found for potassium-after both the first and second year of cultivation. There was a change in the content of this element, depending on the combination of factors used in the experiment; however, not all changes were statistically significant. When analysing the results of the total contents of selected macroelements, it was found that aboveground parts of plants of giant miscanthus contained the least sodium and iron. The fertiliser did not produce statistically significant changes in the contents of these elements in the biomass after the first and second year of cultivation when compared to control tests.

Table 6 presents the total contents of selected microelements and heavy metal $\mathrm{s}$ in the biomass of giant miscanthus, depending on the fertiliser used and the year of research. In the aboveground parts of the plants analysed after the first year of cultivation, manganese, strontium, zinc and aluminium were found. No strontium was recorded in samples obtained after the second year of cultivation. The concentration of these elements was determined to be at a very low level and did not show statistically significant variability between the experimental plots. Plant biomass obtained after the second year of research was characterised by a lower content of the elements analysed when compared to the previous year. In the plant samples studied, no arsenic, cadmium, chromium, copper, molybdenum, nickel or lead was found after both the first and second year of the experiment-values were below the detection limit $\left(0.01 \mathrm{mg} \mathrm{kg}^{-1}\right)$ in the analytical method used. 
Table 5. Contents of selected macroelements in the biomass of giant miscanthus after the first (2016) and second (2017) year of cultivation, depending on the fertiliser used.

\begin{tabular}{|c|c|c|c|c|c|c|c|c|}
\hline \multirow{4}{*}{ Year } & \multirow{4}{*}{ Fertiliser Used } & \multicolumn{7}{|c|}{ Macroelements } \\
\hline & & $\mathrm{Ca}$ & $\mathrm{Fe}$ & $\mathbf{K}$ & $\mathrm{Mg}$ & $\mathrm{Na}$ & $\mathbf{P}$ & $\mathrm{S}$ \\
\hline & & \multicolumn{7}{|c|}{$\mathrm{mg} \mathrm{kg}^{-1}$} \\
\hline & & \multicolumn{7}{|c|}{$\mathrm{x} \pm \mathrm{SD}$} \\
\hline \multirow{8}{*}{2016} & $\mathrm{~B} 1 / \mathrm{P} 1$ & $2.29^{a} \pm 0.16$ & $0.20^{a} \pm 0.05$ & $6.66^{b} \pm 0.32$ & $0.82^{\mathrm{ab}} \pm 0.04$ & $0.13^{a} \pm 0.02$ & $1.28^{b} \pm 0.08$ & $0.92^{\mathrm{a}} \pm 0.06$ \\
\hline & P2 & $2.58^{b} \pm 0.09$ & $0.20^{\mathrm{a}} \pm 0.03$ & $7.71^{c} \pm 0.22$ & $0.89^{b c} \pm 0.10$ & $0.13^{a} \pm 0.02$ & $1.43^{c} \pm 0.11$ & $1.00^{a} \pm 0.07$ \\
\hline & P3 & $2.23^{a} \pm 0.21$ & $0.19^{\mathrm{a}} \pm 0.03$ & $6.03^{a} \pm 0.19$ & $0.74^{\mathrm{a}} \pm 0.11$ & $0.13^{a} \pm 0.01$ & $1.11^{\mathrm{a}} \pm 0.04$ & $0.96^{\mathrm{a}} \pm 0.04$ \\
\hline & P4 & $2.38^{\mathrm{a}} \pm 0.09$ & $0.20^{\mathrm{a}} \pm 0.02$ & $6.93^{b} \pm 0.29$ & $0.91^{b} \pm 0.09$ & $0.13^{\mathrm{a}} \pm 0.01$ & $1.49^{c} \pm 0.03$ & $1.06^{\mathrm{a}} \pm 0.10$ \\
\hline & $\mathrm{B} 2 / \mathrm{P} 1$ & $2.31^{\mathrm{a}} \pm 0.17$ & $0.19^{a} \pm 0.09$ & $5.75^{\mathrm{a}} \pm 0.23$ & $0,74^{a} \pm 0.03$ & $0.12^{\mathrm{a}} \pm 0.01$ & $1.25^{b} \pm 0.06$ & $0.90^{\mathrm{a}} \pm 0.04$ \\
\hline & $\mathrm{B} 2 / \mathrm{P} 2$ & $2.31^{\mathrm{a}} \pm 0.15$ & $0.10^{a} \pm 0.05$ & $7.13^{b} \pm 0.24$ & $0.83^{a b} \pm 0.04$ & $0.12^{a} \pm 0.02$ & $1.29^{b} \pm 0.10$ & $0.99^{a} \pm 0.04$ \\
\hline & $\mathrm{B} 2 / \mathrm{P} 3$ & $2.23^{a} \pm 0.18$ & $0.19^{a} \pm 0.12$ & $7.05^{b} \pm 0.34$ & $0.99^{c} \pm 0.08$ & $0.12^{a} \pm 0.02$ & $1.29^{b} \pm 0.09$ & $1.03^{a} \pm 0.06$ \\
\hline & $\mathrm{B} 2 / \mathrm{P} 4$ & $2.33^{a} \pm 0.18$ & $0.15^{\mathrm{a}} \pm 0.05$ & $6.84^{b} \pm 0.42$ & $1.03^{c} \pm 0.07$ & $0.12^{\mathrm{a}} \pm 0.03$ & $1.31^{\mathrm{b}} \pm 0.11$ & $1.06^{\mathrm{a}} \pm 0.03$ \\
\hline \multirow{8}{*}{2017} & $\mathrm{~B} 1 / \mathrm{P} 1$ & $1.06^{\mathrm{a}} \pm 0.12$ & $0.04^{a} \pm 0.01$ & $5.59^{c} \pm 0.12$ & $0.31^{\mathrm{a}} \pm 0.03$ & $0.09^{a} \pm 0.00$ & $1.13^{c} \pm 0.09$ & $0.38^{\mathrm{ab}} \pm 0.01$ \\
\hline & P2 & $1.13^{a} \pm 0.15$ & $0.06^{a} \pm 0.02$ & $4.90^{b} \pm 0.07$ & $0.34^{b} \pm 0.06$ & $0.08^{a} \pm 0.00$ & $0.97^{b} \pm 0.07$ & $0.34^{a} \pm 0.02$ \\
\hline & P3 & $1.60^{c} \pm 0.06$ & $0.06^{\mathrm{a}} \pm 0.01$ & $5.37^{c} \pm 0.09$ & $0.37^{b} \pm 0.04$ & $0.09^{a} \pm 0.01$ & $1.25^{\mathrm{d}} \pm 0.07$ & $0.47^{c} \pm 0.02$ \\
\hline & P4 & $1.26^{\mathrm{a}} \pm 0.08$ & $0.05^{\mathrm{a}} \pm 0.02$ & $4.58^{\mathrm{a}} \pm 0.12$ & $0.36^{b} \pm 0.01$ & $0.09^{a} \pm 0.01$ & $1.06^{\mathrm{c}} \pm 0.04$ & $0.37 \mathrm{ab} \pm 0.02$ \\
\hline & $\mathrm{B} 2 / \mathrm{P} 1$ & $1.17^{a} \pm 0.12$ & $0.05^{\mathrm{a}} \pm 0.02$ & $4.74^{b} \pm 0.10$ & $0.28^{a} \pm 0.03$ & $0.08^{\mathrm{a}} \pm 0.01$ & $0.95^{b} \pm 0.01$ & $0.32^{a} \pm 0.01$ \\
\hline & $\mathrm{B} 2 / \mathrm{P} 2$ & $1.22^{a} \pm 0.19$ & $0.05^{\mathrm{a}} \pm 0.03$ & $4.34^{\mathrm{a}} \pm 0.08$ & $0.29^{\mathrm{a}} \pm 0.05$ & $0.07^{\mathrm{a}} \pm 0.01$ & $0.81^{\mathrm{a}} \pm 0.09$ & $0.33^{a} \pm 0.03$ \\
\hline & $\mathrm{B} 2 / \mathrm{P} 3$ & $1.15^{\mathrm{a}} \pm 0.03$ & $0.04^{a} \pm 0.02$ & $4.78^{b} \pm 0.11$ & $0.39^{b} \pm 0.10$ & $0.07^{a} \pm 0.01$ & $0.79^{a} \pm 0.08$ & $0.39 \mathrm{ab} \pm 0.03$ \\
\hline & $\mathrm{B} 2 / \mathrm{P} 4$ & $1.44^{\mathrm{b}} \pm 0.07$ & $0.05^{\mathrm{a}} \pm 0.01$ & $4.66^{\mathrm{a}} \pm 0.12$ & $0.40^{\mathrm{b}} \pm 0.05$ & $0.09^{a} \pm 0.00$ & $1.09^{c} \pm 0.07$ & $0.42^{b} \pm 0.02$ \\
\hline
\end{tabular}

$\mathrm{x}$-average, SD-standard deviation. Differences between average values marked with the same Arabic letters (a-d) are not statistically significant at the level of $\alpha \leq 0.05$ according to the Bonferroni test, for each years. 
Table 6. Contents of selected microelements and heavy metals in the biomass of giant miscanthus after the first (2016) and second (2017) year of cultivation, depending on the fertiliser used.

\begin{tabular}{|c|c|c|c|c|c|c|c|c|c|c|c|c|}
\hline \multirow{4}{*}{ Year } & \multirow{4}{*}{$\begin{array}{l}\text { Fertiliser } \\
\text { Used }\end{array}$} & \multicolumn{11}{|c|}{ Microelements } \\
\hline & & Al & As & $\mathrm{Cd}$ & $\mathrm{Cr}$ & $\mathrm{Cu}$ & Mo & $\mathrm{Ni}$ & $\mathrm{Pb}$ & Mn & $\mathrm{Sr}$ & $\mathrm{Zn}$ \\
\hline & & \multicolumn{11}{|c|}{$\mathrm{mg} \mathrm{kg}^{-1}$} \\
\hline & & \multicolumn{11}{|c|}{$x \pm S D$} \\
\hline \multirow{8}{*}{2016} & $\mathrm{~B} 1 / \mathrm{P} 1$ & $0.14^{a} \pm 0.04$ & $<0.01$ & $<0.01$ & $<0.01$ & $<0.01$ & $<0.01$ & $<0.01$ & $<0.01$ & $0.14^{\mathrm{a}} \pm 0.00$ & $0.01^{\mathrm{a}} \pm 0.00$ & $0.07^{\mathrm{a}} \pm 0.03$ \\
\hline & P2 & $0.18^{a} \pm 0.06$ & $<0.01$ & $<0.01$ & $<0.01$ & $<0.01$ & $<0.01$ & $<0.01$ & $<0.01$ & $0.14^{a} \pm 0.02$ & $0.02^{\mathrm{a}} \pm 0.00$ & $0.07^{\mathrm{a}} \pm 0.02$ \\
\hline & P3 & $0.14^{\mathrm{a}} \pm 0.05$ & $<0.01$ & $<0.01$ & $<0.01$ & $<0.01$ & $<0.01$ & $<0.01$ & $<0.01$ & $0.13^{\mathrm{a}} \pm 0.01$ & $0.01^{\mathrm{a}} \pm 0.00$ & $0.06^{\mathrm{a}} \pm 0.02$ \\
\hline & P4 & $0.19^{a} \pm 0.03$ & $<0.01$ & $<0.01$ & $<0.01$ & $<0.01$ & $<0.01$ & $<0.01$ & $<0.01$ & $0.13^{a} \pm 0.01$ & $0.01^{\mathrm{a}} \pm 0.00$ & $0.07^{\mathrm{a}} \pm 0.04$ \\
\hline & $\mathrm{B} 2 / \mathrm{P} 1$ & $0.16^{\mathrm{a}} \pm 0.03$ & $<0.01$ & $<0.01$ & $<0.01$ & $<0.01$ & $<0.01$ & $<0.01$ & $<0.01$ & $0.12^{\mathrm{a}} \pm 0.01$ & $0.01^{\mathrm{a}} \pm 0.00$ & $0.03^{\mathrm{a}} \pm 0.02$ \\
\hline & $\mathrm{B} 2 / \mathrm{P} 2$ & $0.13^{a} \pm 0.03$ & $<0.01$ & $<0.01$ & $<0.01$ & $<0.01$ & $<0.01$ & $<0.01$ & $<0.01$ & $0.12^{\mathrm{a}} \pm 0.02$ & $0.03^{a} \pm 0.04$ & $0.06^{\mathrm{a}} \pm 0.05$ \\
\hline & $\mathrm{B} 2 / \mathrm{P} 3$ & $0.17^{\mathrm{a}} \pm 0.02$ & $<0.01$ & $<0.01$ & $<0.01$ & $<0.01$ & $<0.01$ & $<0.01$ & $<0.01$ & $0.12^{\mathrm{a}} \pm 0.02$ & $0.01^{\mathrm{a}} \pm 0.00$ & $0.05^{\mathrm{a}} \pm 0.03$ \\
\hline & $\mathrm{B} 2 / \mathrm{P} 4$ & $0.16^{\mathrm{a}} \pm 0.03$ & $<0.01$ & $<0.01$ & $<0.01$ & $<0.01$ & $<0.01$ & $<0.01$ & $<0.01$ & $0.12^{a} \pm 0.01$ & $0.01^{\mathrm{a}} \pm 0.00$ & $0.05^{\mathrm{a}} \pm 0.02$ \\
\hline \multirow{8}{*}{2017} & $\mathrm{~B} 1 / \mathrm{P} 1$ & $0.02^{a} \pm 0.00$ & $<0.01$ & $<0.01$ & $<0.01$ & $<0.01$ & $<0.01$ & $<0.01$ & $<0.01$ & $0.09^{a} \pm 0.02$ & $<0.001$ & $0.03^{a} \pm 0.01$ \\
\hline & P2 & $0.03^{a} \pm 0.00$ & $<0.01$ & $<0.01$ & $<0.01$ & $<0.01$ & $<0.01$ & $<0.01$ & $<0.01$ & $0.08^{a} \pm 0.03$ & $<0.001$ & $0.02^{\mathrm{a}} \pm 0.00$ \\
\hline & P3 & $0.05^{\mathrm{a}} \pm 0.00$ & $<0.01$ & $<0.01$ & $<0.01$ & $<0.01$ & $<0.01$ & $<0.01$ & $<0.01$ & $0.09^{\mathrm{a}} \pm 0.01$ & $<0.001$ & $0.03^{\mathrm{a}} \pm 0.01$ \\
\hline & P4 & $0.04^{a} \pm 0.02$ & $<0.01$ & $<0.01$ & $<0.01$ & $<0.01$ & $<0.01$ & $<0.01$ & $<0.01$ & $0.09^{a} \pm 0.01$ & $<0.001$ & $0.02^{\mathrm{a}} \pm 0.01$ \\
\hline & $\mathrm{B} 2 / \mathrm{P} 1$ & $0.02^{\mathrm{a}} \pm 0.01$ & $<0.01$ & $<0.01$ & $<0.01$ & $<0.01$ & $<0.01$ & $<0.01$ & $<0.01$ & $0.08^{a} \pm 0.03$ & $<0.001$ & $0.02^{\mathrm{a}} \pm 0.00$ \\
\hline & $\mathrm{B} 2 / \mathrm{P} 2$ & $0.03^{a} \pm 0.01$ & $<0.01$ & $<0.01$ & $<0.01$ & $<0.01$ & $<0.01$ & $<0.01$ & $<0.01$ & $0.07^{\mathrm{a}} \pm 0.02$ & $<0.001$ & $0.01^{\mathrm{a}} \pm 0.00$ \\
\hline & B2/P3 & $0.03^{\mathrm{a}} \pm 0.01$ & $<0.01$ & $<0.01$ & $<0.01$ & $<0.01$ & $<0.01$ & $<0.01$ & $<0.01$ & $0.07^{\mathrm{a}} \pm 0.02$ & $<0.001$ & $0.02^{\mathrm{a}} \pm 0.01$ \\
\hline & $\mathrm{B} 2 / \mathrm{P} 4$ & $0.03^{\mathrm{a}} \pm 0.00$ & $<0.01$ & $<0.01$ & $<0.01$ & $<0.01$ & $<0.01$ & $<0.01$ & $<0.01$ & $0.09^{a} \pm 0.01$ & $<0.001$ & $0.02^{\mathrm{a}} \pm 0.01$ \\
\hline
\end{tabular}

$\mathrm{x}$-average, $\mathrm{SD}$-standard deviation. Differences between average values marked with the same Arabic letter are not statistically significant at the level of $\alpha \leq 0.05$ according to the Bonferroni test, for each years. 
Principal component analysis of variables (elements) for the biomass of giant miscanthus after the first and second year of cultivation selected two factors describing the level of variability in the group with values, respectively, for the first year: factor $1(27.7 \%)$ and factor $2(21.7 \%)$, and for the second year: factor $1(33.9 \%)$ and factor $2(24.4 \%)$. The selection of the number of main components was made using the scree test and the Kaiser criterion. The first factor included variables such as aluminium, potassium, magnesium, sodium, sulphur (first year) and aluminium, manganese, phosphorus, sulphur (second year). The second factor was represented by variables such as iron, manganese, phosphorus (first year) and calcium, potassium, magnesium (second year). It was noted that factor 1 is most strongly associated with variables $\mathrm{K}$ and $\mathrm{S}$, while factor 2 is associated with variables Fe and Mn (first year). In the second year of research, it was found that factor 1 is mainly associated with variables $\mathrm{S}$ and $\mathrm{Sr}$, while factor 2 is most strongly associated with variable $\mathrm{K}$. The projection of variables on the factor plane is presented in Figure 7.

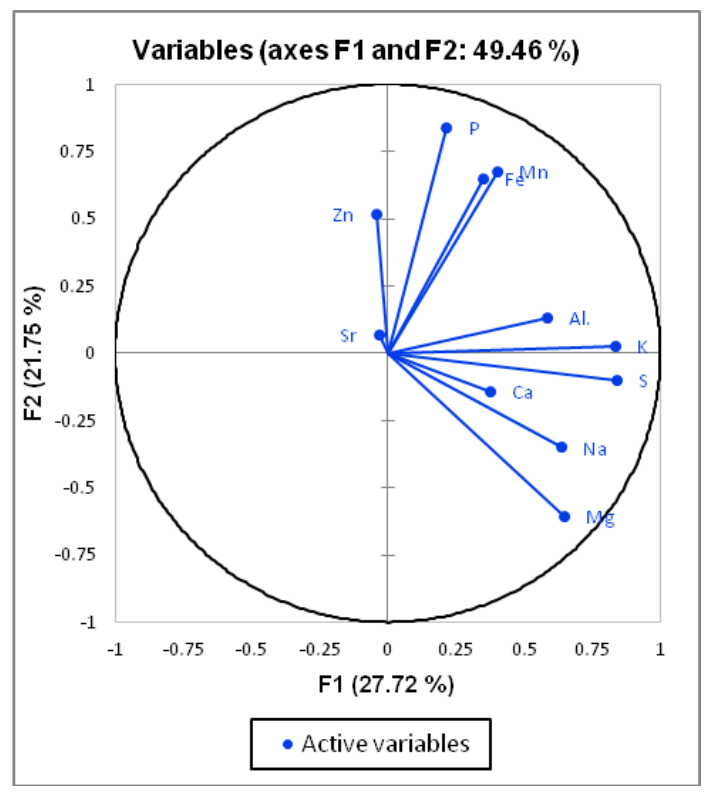

(a)

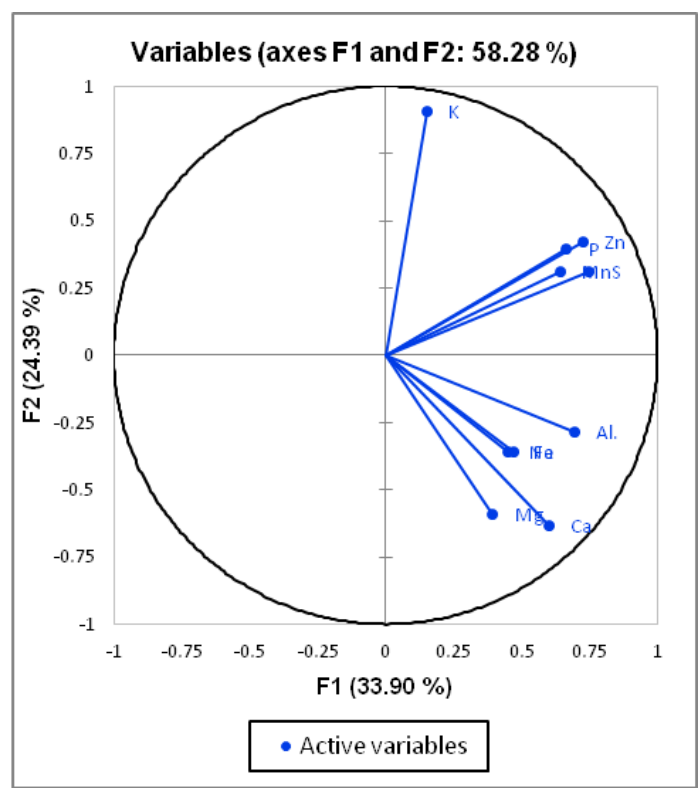

(b)

Figure 7. Variable plot in the system of the first two factor axes for the biomass of giant miscanthus after the first (a) and second (b) year of cultivation.

\section{Discussion}

The cultivation of plants is becoming more and more effective due to the use of numerous means of support, including different types of fertilisers. The agents most commonly used in modern agriculture, which contain easily absorbable mineral components, are fertilisers [24].

Recent years have seen the intensive development of research on the use of unconventional materials as plant fertilisers and for soil reclamation. This research concerns the use of, among other materials, sewage sludge, ash from biomass, brown coal or biochar. In addition, the literature presents only rudimentary information on the use of biochar and ash from biomass as a fertiliser material in the cultivation of perennial energy crops.

The soil reaction plays an important role in many processes occurring in the soil environment. It is important in the uptake of nutrients by plants and affects the mobility of heavy metals, such as cadmium, lead or nickel $[5,16]$. The alkalizing effect associated with the application of biochar to the soil environment relates to the alkaline compound content and the application rate. The clearest changes can be obtained in the case of heavily acidified soils, where a significant decrease is visible in the share of $\mathrm{H}^{+}$and $\mathrm{Al}^{3+}$ [17]. Much of the research conducted so far indicates that the addition of biochar produces an increase in soil $\mathrm{pH}$ [25-28]. Research conducted by Nigussie et al. [29] showed 
that biochar produced from corn stalks and applied to soils contaminated with chromium produced an increase in $\mathrm{pH}$ and ion exchange in the soils analysed. Clear effects on the soil $\mathrm{pH}$ after the application of ashes can be obtained by the application of fertiliser doses at the level of 10-20 $\mathrm{tha}^{-1}$ [30]. However, the use of such high doses of ash could result in the introduction of too large quantities of nutrients or heavy metals into the soil.

According to the analyses performed, the use of fertiliser in the form of a combination of biochar and ash at an application rate of $4.5 \mathrm{tha}^{-1}$ produced the greatest increase in the content of absorbable forms of phosphorus $\left(\mathrm{P}_{2} \mathrm{O}_{5}\right)$, potassium $\left(\mathrm{K}_{2} \mathrm{O}\right)$ and magnesium $(\mathrm{Mg})$ in the soil on which perennial energy crops were grown.

The high potential of biochars for exchangeable ion sorption affects the increase in the concentration of macro- and microelements in the soil profile, which is why it modulates their effective uptake by plants, as well as reduces the risk of their leaching and being displaced to surface and underground waters [12]. The introduction of biochar into the soil may have a positive effect, including on the increase in the phosphorus content in the soil environment. As emphasised by Chan et al. [14], the use of biochar in the soil at a fertiliser dose of more than $50 \mathrm{tha}^{-1}$ significantly increases the concentration of phosphorus in the soil. The increase in the phosphorus content in the soil after the application of biochar results from the content of easily absorbable forms of this element in biochars, as well as from its ability to react on the soil reaction, thus producing changes in the solubility of phosphorus forms [31,32]. Numerous authors report that the addition of biochars to the soil affects the intensive growth of soluble forms of potassium in the soil solution [33,34]. Liu et al. [35] note an increase in the contents of macroelements in the soil compared to the control following the application of biochar from the vegetative parts of bamboo and rice straw. In their paper, the authors used biochars obtained from the pyrolysis process with parameters of $500{ }^{\circ} \mathrm{C}$ and $600{ }^{\circ} \mathrm{C}$ and a process duration of $60 \mathrm{~min}$. Fertiliser doses of biochar from bamboo and rice straw amounted to 5, 18, and $10.5 \mathrm{t} \mathrm{ha}^{-1}$, respectively. According to many authors, ash from plant biomass is characterized by a high amount of the biogenic elements necessary for the proper growth of plants, thanks to which it can supplement deficiencies of macro- and microelements in the soil [36]. Piekarczyk [25] states that the use of ash from wheat straw $\left(1.0 \mathrm{t} \mathrm{ha}^{-1}\right)$ as a fertiliser material produced an increase in absorbable forms of macroelements in the soil, at the same time indicating that these changes were not statistically significant. The author explains this result by the relatively low content of nutrients in the ash used. It should be noted that changes in soil fertility resulting from the introduction of ash depend on the ash source, its elemental composition and the size of the dose applied [37]. In research on the long-term effects of the use of wood ash agents, Klavina et al. [38] note an increase in the concentration of magnesium and phosphorus in peat soils. The authors also inform us about the positive impact of ash on the calcium content and the formation of soil $\mathrm{pH}$.

Biochar and ash from biomass used in field experiments were characterised by total carbon contents of $74.35 \%$ and $1.22 \%$, respectively. This was reflected in the results obtained, which indicate the lack of a fertilising effect of ash itself on changes in the total carbon concentration in the soil. Fertilisers in the form of biochar and its combination with ash produced an increase in the concentration of carbon in the soil, in comparison with the control plot (statistically significant changes in most cases). Similar results were obtained by Doan et al. [39], who reported that the use of biochar from cattle manure in the corn cultivation slightly increased the $C$ content of the soil. In research on the impact of biochar and compost on soil properties in a tropical climate, Ghosh et al. [40] determined that the organic carbon content in the soil after the application of biochar was almost twice as high as in the control plot (an increase from 1.18 to $2.13 \%$ ). It should also be emphasised that stable forms of carbon are characterised by high resistance to biological decomposition, which is why biochar can be treated as an effective agent for carbon sequestration in the soil [11,41,42].

Research conducted as part of the cultivation of giant miscanthus showed that fertilising with a combination of biochar and ash at a dose of $1.5 \mathrm{tha}^{-1}$ produced the greatest increase in the total calcium, sodium and sulphur contents after the first and second year of cultivation, when compared to 2015 . 
For the aforementioned fertiliser, a decrease was noted in the total concentration of the microelements in 2016 and 2017 when compared to their concentration before the experiment. Many researchers point to biochar's great potential as a material that can be used to reduce the mobility of heavy metals in the soil $[43,44]$. According to Bielinska et al. [45], ash from fluidised bed combustion of hard coal used for agricultural purposes did not produce an increase in the amount of zinc, copper and cadmium in the soil. One of the key features of energy crops should be the high level of biomass productivity. On the basis of the research conducted, it was found that the highest yield of dry matter of giant miscanthus plants, both after the first and second year of cultivation, was obtained by fertilising with ash at an application rate of $1.5 \mathrm{t} \mathrm{ha}^{-1}$, with biochar, and the combination of biochar and ash at a dose of $1.5 \mathrm{t} \mathrm{ha}^{-1}$. The aforementioned fertilisers produced an increase in yield in 2016 compared to the control plots by 17\%, 17\% and 68\%, respectively. The dry matter yield of plants recorded in 2017 was several times higher than in the previous year, and the recorded changes for the aforementioned factors in relation to the control plots were $8 \%, 48 \%$ and $11 \%$, respectively. In research on the yield of osier cultivated using the Eko-Salix system (five-year rotation), Szczukowski et al. [46] determined the dry matter yield of plants to be on average $7.46 \mathrm{t} \mathrm{ha}^{-1}$ per year. Kwasniewski [47] states that the average yield of fresh biomass of energy willow obtained from 30 selected plantations located in Poland was $7.0 \mathrm{t} \mathrm{ha}^{-1}$ (first year of cultivation). Field experiments carried out so far in Poland have shown that the average yield of willow cultivated using the short rotation system ranged from 10 to $15 \mathrm{tha}^{-1}$ of dry matter [48,49]. Kobylinski and Olszewska [50], conducting research on energy efficiency in the production of giant miscanthus, recorded a dry matter yield of plants of $1.5 \mathrm{t} \mathrm{ha}^{-1}$ in the first year of cultivation and $9 \mathrm{t} \mathrm{ha}^{-1}$ in the second year of cultivation. These values increased to the level of $15 \mathrm{t} \mathrm{ha}^{-1}$ in the third year of cultivation. The authors claim that the slow rate of plant development in the early period of cultivation, environmental conditions and the small doses of mineral fertilisers affected the low biomass yield obtained in the first year. It should also be emphasised that the full yield of perennial energy crops may be obtained after 3-4 years of cultivation.

Research conducted by Puchalski et al. [51] confirms the positive effect of the use of plant biomass ash on the yield of two varieties of topinambour (Helianthus tuberosus L.). The fertiliser dose used was $12.8 \mathrm{t} \mathrm{ha}^{-1}$, which produced an increase in the dry matter yield of plants after the first year of cultivation compared to the control plot of $7 \%$ for the Albik variety and $21 \%$ for the Gigant variety. However, it should be noted that the lower doses of ash used in the experiment did not produce statistically significant changes in the yield. In our own research, a significant increase in the yield of osier and giant miscanthus was obtained after the application of ash at a dose of $1.5 \mathrm{tha}^{-1}$. The majority of research conducted so far on the response of giant miscanthus to the fertiliser applied concerned the use of inorganic nitrogen. However, the results obtained were contradictory and did not give a definite answer concerning the positive effect that fertilising with nitrogen has on plants. Many authors state that fertilising with nitrogen did not affect the growth and yield of various types of miscanthus [52-55].

Research conducted so far on the use of biochar in plant production has concentrated in the area of cultivation of such plants as corn, radish, rape, rice and potatoes [14,43,56-58]. According to Liu et al. [59], the use of biochar at doses below $30 \mathrm{t} \mathrm{ha}^{-1}$ (field conditions) produced, to varying degrees, an increase in the yield depending on the type of cultivation. The authors note a growth in crop yield of 30\%, 29\%, 13\%, 11\%, 8\% and 7\%, respectively, for legumes, vegetables, grasses, wheat, corn and rice. The literature also states that biochars from sewage sludge can be used for the fertilisation of plants. Hossain et al. [60], following the use of $10 \mathrm{tha}^{-1}$ of biochar from sewage sludge in the cultivation of cherry tomatoes, obtained a $64 \%$ increase in production, compared to the control plot. However, it should be noted that there is an upper limit to the amount of biochar that should be applied with respect to crop productivity. Lehmann et al. [61] note that plants respond positively to the addition of biochar to the soil at doses of up to $55 \mathrm{t} \mathrm{ha}^{-1}$. The authors report that the use of higher doses does not produce a statistically significant impact on the increase in plant yield. Increased plant production due to the use of biochar as a fertiliser material can be observed as changes in plant growth, nutrient uptake and yield [62]. It should be noted that the research conducted so far has been 
of a short-term character; therefore, the assessment of the long-term impact of biochar on the soil and plants seems to be justified.

The calorific value of the biomass of giant miscanthus harvested after two years of research ranged from 17.54 to $17.75 \mathrm{MJ} \mathrm{kg}^{-1}$ of d.m. There were no statistically significant changes in the parameters investigated after the use of fertilisation factors. The results obtained are consistent with the data contained in the available literature [63-65].

The average total contents of the elements studied in the biomass of giant miscanthus after the first and second year of cultivation were determined to be a series of decreasing values of $\mathrm{K}>\mathrm{Ca}$ $>\mathrm{P}>\mathrm{S}>\mathrm{Mg}>\mathrm{Al}>\mathrm{F}$ e $\mathrm{Mn}>\mathrm{Zn}>\mathrm{Na}>\mathrm{Sr}$ and $\mathrm{K}>\mathrm{Ca}>\mathrm{P}>\mathrm{S}>\mathrm{Mg}>\mathrm{Mn}>\mathrm{Fe}>\mathrm{Al}>\mathrm{Zn}>\mathrm{Na}$. In 2017, there was a decrease in the average total contents of the macroelements analysed in the biomass obtained from experiments in relation to the previous year. Similar results were obtained by Borkowska and Lipinski [66] in research on the contents of selected elements in the biomass of energy crops. These authors recorded a high concentration of calcium and potassium in comparison with other elements for giant miscanthus, sugar miscanthus and two clones of osier. According to Szyszlak-Barglowicz [67], various levels of mineral fertilisation did not significantly affect the contents of macroelements studied in the biomass of Virginia fanpetals. The analysis of the concentration of $\mathrm{N}$, $\mathrm{P}, \mathrm{K}, \mathrm{Ca}$ and $\mathrm{Mg}$ in the stems and leaves of the study plants showed the highest content of potassium and calcium.

No harmful compounds such as arsenic, cadmium, chromium and lead were found in the biomass of the aboveground parts of plants collected from experimental plots. Academic literature states that with the increase in concentration of heavy metals in the substrate, we should expect an increase in the contents of metals in the biomass of miscanthus. Experiments confirm this relationship with respect to cadmium and copper. In the case of the cultivation of miscanthus on a substrate contaminated with lead, there were no significant changes in the content of this element in plants [68]. In research on the impact of fertilisation with sewage sludge on the contents of heavy metals in osier, Kalembasa et al. [69] note the lack of a significant dependence between the lead content in leafless plant shoots as controls and items with fertiliser treatments. However, the authors note that plants from plots on which the highest fertiliser dose was applied contained more heavy metals than those fertilised with a smaller amount of sewage sludge. Bearing in mind the environmental aspects, particular attention should be paid to the potential presence of heavy metals in plant biomass for energy purposes, and one should conduct in-depth qualitative characteristics [70].

\section{Materials and Methods}

\subsection{Site Description}

Two-year field trials were conducted in Krasne (Subcarpathian Voivodship, Poland, 50 $04^{\prime} 16.1^{\prime \prime} \mathrm{N}$ $22^{\circ} 04^{\prime} 37.6^{\prime \prime}$ E) over 2015-2017. They were located on arable land of the IVb land quality class in split-block system in four repetitions. The total number of plots in the field experiment was 32; the area of each was $35 \mathrm{~m}^{2}$ (7 $\mathrm{m}$ length, $5 \mathrm{~m}$ width) and to the harvest $24 \mathrm{~m}^{2}$ ( $6 \mathrm{~m}$ length, $4 \mathrm{~m}$ width).

\subsection{Experimental Design}

The area covered by the research was agricultural fallow left without any intervention for more than 10 years. In order to prepare the soil for cultivation (autumn 2013), mulching was performed with a bush cutter, followed by weeding in the form of a Roundup 360 SL spray (dose: 61 ha $^{-1}$ ); after two weeks, disc ploughs and deep ploughing were performed using a mouldboard plough. In the spring of 2015, treatments for improving the soil (levelling the land surface, breaking up the soil lumps and destroying emerging weeds) were performed in the form of harrowing, with the use of a passive pneumatic seed drill. Based on the results of analyses performed before the experiment and the nutritional needs of plants, recommendations for fertiliser application were developed. Fertiliser treatments with biochar at a dose of $11.5 \mathrm{tha}^{-1}$, ash from biomass at doses of 1.5, 3.0, $4.5 \mathrm{tha}^{-1}$ and a 
combination of these were used. In April 2015, fertilizers were sown manually, and then mixed with the soil to a depth of approximately $20 \mathrm{~cm}$ by means of a rototiller. Seedlings of giant miscanthus were obtained from a private supplier (Lublin Voivodship, Poland). On 16 April 2015, seedlings were manually planted on the experimental plots: planting depth: $10-15 \mathrm{~cm}$; spacing of seedlings: $1 \mathrm{~m}$; spacing of rows: $0.8 \mathrm{~m}$; density: 13,000 plants ha ${ }^{-1}$. The biomass harvest from the plots was performed in February 2016 and 2017 using a brushcutter with a cutting disc, rejecting extreme rows (height of the cut above the soil surface- $10 \mathrm{~cm}$ ). In the second year of the experiment, no re-application of fertiliser in the form of biochar and ash from biomass was carried out.

\subsection{Fertiliser Material}

The biochar, in the form of coal scales, originated from the processing of biomass from energy crops (commercially available, Poland). The fertiliser material in the form of ash from the combustion of a mixture of biomass from energy crops and plant biomass of agricultural origin was obtained from the Tauron power station (Stalowa Wola, Poland). Biochar was subjected to a grinding process with the use of the Laarmann CM-1000 high-speed cutting mill. The grinding process was performed using a sieve with a mesh size of $10 \mathrm{~mm}$. Ash generated from the combustion of plant biomass did not require additional treatment before its application.

\subsection{Biomass Production}

The yield of plants was assessed at the end of each growing season. The plant material collected was dried at $70{ }^{\circ} \mathrm{C}$, weighed and the biomass yield of dry matter in $\mathrm{tha}^{-1}$ was calculated.

\subsection{Examination of Samples}

Samples of soil, biochar, ash from biomass and the aboveground parts of giant miscanthus plants were subjected to laboratory analyses using current analytical standards (Table 7).

Table 7. Parameters analysed with research methods.

\begin{tabular}{|c|c|c|}
\hline Item & Parameter & Research Method \\
\hline 1 & $\mathrm{pH} w \mathrm{KCl}$ & PN-ISO 10390:1997 [71] \\
\hline 2 & $\begin{array}{l}\text { Content of absorbable forms of } \\
\text { phosphorus }\left(\mathrm{P}_{2} \mathrm{O}_{5}\right)\end{array}$ & PN-R-04023:1996 [72] \\
\hline 3 & $\begin{array}{l}\text { Content of absorbable forms of } \\
\text { potassium }\left(\mathrm{K}_{2} \mathrm{O}\right)\end{array}$ & PN-R-04022:1996/Az1:2002 [73] \\
\hline 4 & $\begin{array}{l}\text { Content of absorbable form of } \\
\text { magnesium }(\mathrm{Mg})\end{array}$ & PN-R-04020:1996/Az1:2004 [74] \\
\hline 5 & $\begin{array}{c}\text { Content of carbon, nitrogen and } \\
\text { hydrogen }\end{array}$ & PN-EN 15104:2011 [75] \\
\hline 6 & Ash content & PN-EN 13775:2010 [76] \\
\hline 7 & Content of volatile substances & PN-EN 15138:2011 [77] \\
\hline 8 & Calorific value & PN-EN 13918:2010 [78] \\
\hline 9 & $\begin{array}{l}\text { Total content of selected macro- } \\
\text { and microelements }\end{array}$ & $\begin{array}{l}\text { Method using atomic emission spectrometry with } \\
\text { excitation in argon plasma (ICP-OES) }\end{array}$ \\
\hline
\end{tabular}

The determination of the $\mathrm{pH}$ of the study materials was performed by measuring the concentration of hydrogen ions, i.e., the activity of hydrogen ions $\left(\mathrm{H}^{+}\right)$with the use of the potentiometric method. The analysis was performed in $\mathrm{KCl}$ solution with a concentration of $1 \mathrm{~mol} \mathrm{dm}^{-3}$, assuming a mass ratio of the study sample to solution volume of 1:2.5. Measurements were performed using the Nahita $\mathrm{pH}$ meter, model 907 (AUXILAB, Beriáin, Spain).

Analyses of the contents of ash and volatile substances in the study materials using thermogravimetric methods were performed using the TGA 701 apparatus by LECO (LECO Corporation, Saint Joseph, MI, USA). The content of total carbon and nitrogen was tested using the TrueSpec CHN analyser by LECO (LECO Corporation, Saint Joseph, MI, USA).The AC500 calorimeter 
by LECO (LECO Corporation, Saint Joseph, MI, USA) was used to determine the calorific value of the materials analysed.

The mineralisation of the study material was performed in three repetitions. Contents of elements in samples were determined using a method based on inductively coupled plasma atomic emission spectroscopy (ICP-OES), with the use of the iCAP Dual 6500 analyser (Thermo Fisher Scientific, Schaumburg, IL, USA). The mineralisation of the study samples was performed in Teflon containers using a mixture of acids under specific conditions (Table 8). In each case, a 0.2-g sample was mineralised. The sample obtained in this way was supplemented with mineralised water to make a volume of $50 \mathrm{~mL}$. In the calibration step, standard solutions for all elements were prepared from the spectroscopic grade reagent (Thermo) with a three-step curve. The curve fit factor for all elements was over 0.99 . Selection of a measuring line of appropriate length was validated by the method of standard additions. The recovery on selected lines was above $98.5 \%$ for each of the elements. Each time, the CRM 1515 (Certified Reference Material) was used and the selection of appropriate lines was implemented using the standard addition method. Each time we also used internal standards for matrix curve correction; these were Yttrium $(\mathrm{Y})$ and Ytterbium $(\mathrm{Yb})$, two elements not detected in the samples. The detection limit of the analytical method used for the elements studied was no worse than $0.01 \mathrm{mg} \mathrm{kg}^{-1}$ [79].

Table 8. Parameters of the mineralisation process.

\begin{tabular}{|c|c|c|c|c|}
\hline Material & Acid & Temperature and Time & Power & Application Note \\
\hline Soil & $\begin{array}{c}8 \mathrm{~mL} \mathrm{HNO}_{3} 65 \% \\
5 \mathrm{~mL} \mathrm{HCl} 37 \% \\
1 \mathrm{~mL} \mathrm{HF} 40 \% \\
5 \mathrm{~mL} \mathrm{H}_{3} \mathrm{BO}_{3} 5 \%\end{array}$ & \multirow{3}{*}{$\begin{array}{l}\text {-temperature increase to } 200{ }^{\circ} \mathrm{C} \text {, } \\
\text { time: } 15 \mathrm{~min} \text {; } \\
\text { - maintaining at temperature of } \\
200{ }^{\circ} \mathrm{C}, \\
\text { time: } 15 \mathrm{~min}\end{array}$} & \multirow[t]{4}{*}{$1500 \mathrm{~W}$} & HPR-EN-13 [80] \\
\hline Biochar & $\begin{array}{l}7 \mathrm{~mL} \mathrm{HNO}_{3} 65 \% \\
1 \mathrm{~mL} \mathrm{H}_{2} \mathrm{O}_{2} 30 \%\end{array}$ & & & HPR-PE-19 [81] \\
\hline Plant biomass & $\begin{array}{l}6 \mathrm{~mL} \mathrm{HNO}_{3} 65 \% \\
2 \mathrm{~mL} \mathrm{H}_{2} \mathrm{O}_{2} 30 \%\end{array}$ & & & HPR-AG-02 [82] \\
\hline Ash from biomass & $\begin{array}{c}7 \mathrm{~mL} \mathrm{HNO}_{3} 65 \% \\
1 \mathrm{~mL} \mathrm{HCl} 37 \% \\
1.5 \mathrm{~mL} \mathrm{HF} 40 \%\end{array}$ & $\begin{array}{l}\text { - temperature increase to } 220^{\circ} \mathrm{C} \text {, } \\
\text { time: } 20 \mathrm{~min} \text {; } \\
\text { - maintaining at temperature of } \\
220{ }^{\circ} \mathrm{C}, \\
\text { time: } 15 \mathrm{~min}\end{array}$ & & HPR-EN-04 [83] \\
\hline
\end{tabular}

\subsection{Statistical Analyses}

The verification of the influence of the experimental factors used on the parameters analysed and existing dependencies was performed using ANOVA statistical analysis by means of the Bonferroni post hoc test. A materiality level of $\alpha \leq 0.05$ was applied. Principal component analysis (PCA) was also applied. This indirect ordination technique allows one to analyse a large number of variables to detect structure and regularity in relationships between them. Statistical analyses were performed using Statistica 12 software (StatSoft Polska, Krakow, Poland).

\section{Conclusions}

While verifying the research hypothesis, it should be stated that biochar and ash from plant biomass can be used as a fertiliser in the cultivation of energy crops. The results of research presented in this paper confirm that biochar and ash from biomass used at an appropriate dose have a positive effect on the chemical properties of the soil and increase the yield of giant miscanthus. The result of the research indicates that biochar is a better fertiliser than biomass ash due to the wider spectrum of activity. However, the research conducted needs to be continued in order to monitor soil properties and assess the crop yield to be obtained in the following years. Deepening knowledge in this area is an attempt to direct the circulation of inorganic matter in the environment, and at the same time forms an important support for environmental protection, with particular emphasis on phytoremediation and the utilitarian dimension of sustainable energy management. The introduction of biochar into the soil 
in combination with ash from biomass may be an alternative to traditional forms of mineral fertiliser, as well as a means to strengthen the ecological aspect of agro-energy.

Author Contributions: Conceptualization, B.S.; Data curation, B.S. and G.Z.; Formal analysis, B.S., G.Z., M.B. and M.C.; Methodology, B.S., G.Z., M.B. and M.C.; Project administration, C.P.; Supervision, C.P.; Writing-original draft, B.S. and G.Z.; Writing-review \& editing, C.P.

Funding: This research received no external funding.

Conflicts of Interest: The authors declare no conflict of interest.

\section{References}

1. Kumar, P.; Barret, D.M.; Delwiche, M.J.; Stroeve, P. Methods for pretreatment of lignocellulosic biomass for efficient hydrolysis and biofuel production. Ind. Eng. Chem. Res. 2009, 48, 3713-3729. [CrossRef]

2. Tripathi, M.; Sahu, J.N.; Ganesan, P. Effect of process parameters on production of biochar from biomass waste through pyrolysis: A review. Renew. Sustain. Energy Rev. 2016, 55, 467-481. [CrossRef]

3. Kalembasa, D. Amount and chemical composition of ash from biomass of energy crops. Acta Agrophys. 2006, 7, 909-913.

4. Pels, J.R.; Nie, D.S.; Kiel, J.H.A. Utilization of ashes from biomass combustion and gasification. In Proceedings of the 13th European Biomass Conference \& Exhibition, Paris, France, 17-21 October 2005.

5. Medyńska-Juraszek, A. Biochar as an addition to soils. Soil Sci. Annu. 2016, 67, 151-157. [CrossRef]

6. Laird, D.; Fleming, P.; Davis, D.; Horton, R.; Wang, B.; Karlen, D. Impact of biochar amendments on the quality of a typical Midwestern agricultural soil. Geoderma 2010, 158, 443-449. [CrossRef]

7. Macdonald, L.; Farrell, M.; Van Zwieten, L.; Krull, E. Plant growth responses to biochar addition: An Australian soils perspective. Biol. Fertil. Soils 2013, 50, 1035-1045. [CrossRef]

8. Beesley, L.; Moreno-Jiménez, E.; Gomez-Eyles, J.; Harris, E.; Robinson, B.; Sizmur, T. A review of biochars' potential role in the remediation, revegetation and restoration of contaminated soils. Environ. Pollut. 2011, 159, 3269-3282. [CrossRef] [PubMed]

9. Cross, A.; Sohi, S. The priming potential of biochar products in relation to labile carbon contents and soil organic matter status. Soil Biol. Biochem. 2011, 43, 2127-2134. [CrossRef]

10. Zhang, Q.; Du, Z.; Lou, Y.; He, X. A one-year short-term biochar application improved carbon accumulation in large macro aggregate fractions. Catena 2015, 127, 26-31. [CrossRef]

11. Lehmann, J.; Rilling, M.C.; Thies, J.; Masiello, C.A.; Hockaday, W.C.; Crowley, D. Biochar effects on soil biota-A review. Soil Biol. Biochem. 2011, 43, 1812-1836. [CrossRef]

12. Laird, D.A. The charcoal vision: A win-win-win scenario for simultaneously producing bioenergy, permanently sequestering carbon, while improving soil and water quality. Agron. J. 2008, 100, 178-181. [CrossRef]

13. Chan, K.Y.; Van Zwieten, L.; Meszaros, I.; Downie, A.; Joseph, S. Agronomic values of green waste biochar as a soil amendment. Aust. J. Soil Res. 2007, 45, 629-634. [CrossRef]

14. Woolf, D.; Amonette, J.E.; Street-Perrott, F.A.; Lehmann, J.; Joseph, S. Sustainable biochar to mitigate global climate change. Nat. Commun. 2010, 1, 56. [CrossRef] [PubMed]

15. Yuan, J.; Xu, R.; Zhang, H. The forms of alkalis in the biochar produced from crop residues at different temperatures. Bioresour. Technol. 2011, 102, 3488-3497. [CrossRef] [PubMed]

16. Novak, J.M.; Busscher, W.J.; Laird, D.L.; Ahmedna, M.; Watts, D.W.; Niandou, M.A.S. Impact of biochar amendment on fertility of a Southeastern coastal plain soil. Soil Sci. 2009, 174, 105-112. [CrossRef]

17. Zong, Y.; Xiao, Q.; Lu, S. Acidity, water retention, and mechanical physical quality of a strongly acidic Ultisol amended with biochars derived from different feedstocks. J. Soil Sediment 2006, 16, 177-190. [CrossRef]

18. Jien, S.; Wang, C. Effects of biochar on soil properties and erosion potential in a highly weathered soil. Catena 2013, 110, 225-233. [CrossRef]

19. Agegnehu, G.; Bass, A.; Nelson, P.; Bird, M. Benefits of biochar, compost and biochar-compost for soil quality, maize yield and greenhouse gas emissions in a tropical agricultural soil. Sci. Total Environ. 2016, 543, $295-306$. [CrossRef] [PubMed]

20. Das, O.; Sarmah, A. The love-hate relationship of pyrolysis biochar and water: A perspective. Sci. Total Environ. 2015, 512/513, 682-685. [CrossRef] [PubMed] 
21. Cayuela, M.; Van Zwieten, L.; Singh, B.; Jeffery, S.; Roig, A.; Sanchez-Monedero, M.A. Biochar's role in mitigating soil nitrous oxide emissions: A review and meta-analysis. Agric. Ecosyst. Environ. 2013, 191, 5-16. [CrossRef]

22. Cadoux, S.; Riche, A.B.; Yates, N.E.; Machet, J.M. Nutrient requirements of Miscanthus x giganteus: Conclusions from a review of published studies. Biomass Bioenergy 2012, 38, 13-22. [CrossRef]

23. Lewandowski, I.; Scurlock, J.M.O.; Lindvall, E.; Christou, M. The development and current status of perennial rhizomatous grasses as energy crops in the US and Europe. Biomass Bioenergy 2003, 25, 335-361. [CrossRef]

24. Landrat, M.; Waluda, T. Possibilities of fertilizer using of rabbit manure. Arch. Waste Manag. Environ. Prot. 2016, 18, 25-32.

25. Piekarczyk, M. Content of absorbable forms of some macro- and microelements in light soil fertilized with ash from winter wheat straw. Fragm. Agron. 2013, 30, 92-98.

26. Butnan, S.; Deenik, J.L.; Toomsan, B.; Antal, M.J.; Vityakon, P. Biochar characteristics and application rates affecting corn growth and properties of soils contrasting in texture and mineralogy. Geoderma 2015, 237, 105-116. [CrossRef]

27. Case, S.D.C.; McNamara, N.P.; Reay, D.S.; Whitaker, J. The effect of biochar addition on $\mathrm{N}_{2} \mathrm{O}$ and $\mathrm{CO}_{2}$ emissions from a sandy loam soil-The role of soil aeration. Soil Biol. Biochem. 2012, 51, 125-134. [CrossRef]

28. Lai, W.Y.; Lai, C.M.; Ke, G.R.; Chung, R.S.; Chen, C.T.; Cheng, C.H.; Pai, C.W.; Chen, S.Y.; Chen, C. The effects of woodchip biochar application on crop yield, carbon sequestration and greenhouse gas emissions from soils planted with rice or leaf beet. J. Taiwan Inst. Chem. Eng. 2013, 44, 1039-1044. [CrossRef]

29. Nigussie, A.; Kissi, E.; Misganaw, M.; Ambaw, G. Effect of biochar application on soil properties and nutrient uptake of lettuces (Lactuca sativa) grown in chromium polluted soils. Am.-Eurasian. J. Agric. Environ. Sci. 2012, 12, 369-376.

30. Park, B.B.; Yanai, R.D.; Sahm, J.M.; Lee, D.K.; Abrahamson, L.P. Wood ash effects on plant and soil in a willow bioenergy plantation. Biomass Bioenergy 2005, 28, 355-365. [CrossRef]

31. Turner, B.L.; Frossard, E.; Oberson, A. Biological Approaches to Sustainable Soil Systems; Enhancing phosphorus availability in low-fertility soils; Taylor \& Francis: Abingdon, UK, 2006; pp. 191-205.

32. Chintala, R.; Schumacher, T.; McDonald, L.; Clay, D.; Malo, D.; Papiernik, S.; Clay, S.; Julson, J. Phosphorus sorption and availability from biochars and soil/biochar mixtures. Clean-Soil Air Water 2013, 42, 626-634. [CrossRef]

33. Oram, N.; van de Voorde, T.; Ouwehand, G.; Bezemer, T.; Mommer, L.; Jeffery, S.; van Groenigen, J. Soil amendment with biochar increases the competitive ability of legumes via increased potassium availability. Agric. Ecosyst. Environ. 2013, 191, 92-98. [CrossRef]

34. Widowati, W.; Asnah, A. Biochar can enhance potassium fertilization efficiency and economic feasibility of maize cultivation. J. Agric. Sci. 2013, 6, 24-32. [CrossRef]

35. Liu, Y.; Lu, H.; Yang, S.; Wang, Y. Impacts of biochar addition on rice yield and soil properties in a cold waterlogged paddy for two crop seasons. Field Crops Res. 2016, 191, 161-167. [CrossRef]

36. James, A.K.; Thring, R.W.; Helle, S.; Ghuman, H.S. Ash management review-Applications of biomass bottom ash. Energies 2012, 5, 3856-3873. [CrossRef]

37. Bakisgan, C.; Dumanli, A.G.; Yürüm, Y. Trace elements in Turkish biomass fuels: Ashes of wheat straw, olive bagasse and hazelnut shell. Fuel 2009, 88, 1842-1851. [CrossRef]

38. Klavina, D.; Pennanen, T.; Gaitnieks, T.; Velmala, S.; Lazdins, A.; Lazdina, D.; Menkis, A. The ectomycorrhizal community of conifer stands on peat soils 12 years after fertilization with wood ash. Mycorrhiza 2016, 26, 153-160. [CrossRef] [PubMed]

39. Doan, T.T.; Henry-des-Tureaux, T.; Rumpel, C.; Janeau, J.L.; Jouquet, P. Impact of compost, vermicompost and biochar on soil fertility, maize yield and soil erosion in northern Vietnam: A three-year mesocosm experiment. Sci. Total Environ. 2015, 513, 137-154. [CrossRef] [PubMed]

40. Ghosh, S.; Ow, L.F.; Wilson, B. Influence of biochar and compost on soil properties and tree growth in a tropical urban environment. Int. J. Environ. Sci. Technol. 2015, 12, 1303-1310. [CrossRef]

41. Spokas, K.A.; Cantrell, K.B.; Novak, J.M.; Archer, D.A.; Ippolito, J.A.; Collins, H.P.; Boateng, A.A.; Lima, I.M.; Lamb, M.C.; McAloon, A.J.; et al. Biochar: A synthesis of its agronomic impact beyond carbon sequestration. J. Environ. Qual. 2012, 41, 973-989. [CrossRef] [PubMed]

42. Kuzyakov, Y.; Subbotina, I.; Chen, H.; Bogomolova, I.; Xu, X. Black carbon decomposition and incorporation into soil microbial biomass estimated by 13C labeling. Soil Biol. Biochem. 2009, 41, 210-219. [CrossRef] 
43. Liu, Z.; Chen, X.; Jing, Y.; Li, Q.; Zhang, J.; Huang, Q. Effects of biochar amendment on rapeseed and sweet potato yields and water stable aggregate in upland red soil. Catena 2013, 123, 45-51. [CrossRef]

44. Puga, A.P.; Abreu, C.A.; Melo, L.C.A.; Paz-Ferreiro, J.; Beesley, L. Cadmium, lead and zinc mobility and plant uptake in a mine soil amended with sugarcane straw biochar. Environ. Sci. Pollut. Res. 2015, 22, 17606-17613. [CrossRef] [PubMed]

45. Bielińska, E.J.; Baran, S.; Stankowski, S. Assessment of the suitability of fluidized ashes from hard coal for agricultural purposes. Agric. Eng. 2009, 6, 7-13.

46. Szczukowski, S.; Stolarski, M.; Tworkowski, J. Yielf of willow biomass manufactured with the eco-salix system. Fragm. Agron. 2011, 28, 104-115.

47. Kwaśniewski, D. Energy efficiency of biomass production from the annual willow. Agric. Eng. 2010, 1, 289-295.

48. Szczukowski, S.; Stolarski, M.; Tworkowski, J.; Rutkowski, P.; Goliński, P.; Mleczek, M.; Szentner, K. Yield and quality of biomass of selected willow species in the four-year harvest rotation. Fragm. Agron. 2013, 31, 107-113.

49. Jeżowski, S.; Głowacka, K.; Kaczmarek, Z.; Szczukowski, S. Field traits of eight common osier clones in the first three years following planting in Poland. Biomass Bioenergy 2011, 35, 1205-1210.

50. Kobyliński, A.; Olszewska, M. Energy efficiency of biomass production Miscanthus giganteus. Grassl. Sci. Pol. 2013, 16, 19-28.

51. Puchalski, C.; Zapałowska, A.; Hury, G. The impact of sewage sludge and biomass ash fertilization on the yield, including biometric features and physiological parameters of plants of two jerusalem artichoke (Helianthus tuberosus L.) cultivars. Folia Pomer. Univ. Technol. Stetin. Agric. Aliment Pisc. Zootech. 2017, 332, 37-52.

52. Boehmel, C.; Claupein, W. Contribution to bioenergy production by different annual and perennial cropping systems. In Proceedings of the 15th European Biomass Conference, Berlin, Germany, 7-11 May 2007.

53. Christou, M.; Mardikis, M.; Alexopoulou, E. Research on the effect of irrigation and nitrogen upon growth and yields of Arundo donax L. in Greece. Asp. Appl. Biol. 2001, 65, 47-55.

54. Danalatos, N.; Archontoulis, S.; Mitsios, I. Potential growth and biomass productivity of Miscanthus x giganteus as affected by plant density and N-fertilization in central Greece. Biomass Bioenergy 2007, 31, 31-152. [CrossRef]

55. Smith, R.; Slater, F.M. The effects of organic and inorganic fertilizer applications to Miscanthus $\mathrm{x}$ giganteus, Arundo donax and Phalaris arundinacea, when grown as energy crops in Wales, UK. GCB. Bioenergy 2010, 2, 169-179. [CrossRef]

56. Chan, K.Y.; Van Zwieten, L.; Meszaros, I.; Downie, A.; Joseph, S. Using poultry litter biochars as soil amendments. Aust. J. Soil Res. 2008, 46, 437-444. [CrossRef]

57. Glaser, B.; Lehmann, J.; Zech, W. Ameliorating physical and chemical properties of highly weathered soils in the tropics with charcoal-Review. Biol. Fertil Soils 2002, 35, 1719-1730. [CrossRef]

58. Uzoma, K.C.; Inoue, M.; Andry, H.; Fujimaki, H.; Zahoor, A.; Nishihara, E. Effect of cow manure biochar on maize productivity under sandy soil condition. Soil Use Manag. 2011, 27, 205-212. [CrossRef]

59. Liu, X.; Zhang, A.; Ji, C.; Joseph, S.; Bian, R.; Li, L.; Pan, G.; Paz-Ferreiro, J. Biochar's effect on crop productivity and the dependence on experimental conditions-A meta-analysis of literature data. Plant Soil 2013, 373, 583-594. [CrossRef]

60. Hossain, M.K.; Strezov, V.; Chan, K.Y.; Nelson, P.F. Agronomic properties of wastewater sludge biochar and bioavailability of metals in production of cherry tomato (Lycopersicon esculentum). Chemosphere 2010, 78, 1167-1171. [CrossRef] [PubMed]

61. Lehmann, J.; Gaunt, J.; Rondon, M. Biochar sequestration in terrestrial ecosystems-A review. Mitig. Adapt. Strateg. Glob. Chang. 2006, 11, 395-419. [CrossRef]

62. Gao, S.; DeLuca, T.H. Influence of biochar on soil nutrient transformations, nutrient leaching and crop yield. Adv. Plants Agric. Res. 2016, 4, 00150.

63. Klašnja, B.; Orlović, S.; Galić, Z. Comparison of different wood species as raw materials for bioenergy. South-East Eur. For. 2013, 4, 81-88. [CrossRef]

64. Kołodziej, B.; Antonkiewicz, J.; Sugier, D. Miscanthus x giganteus as a biomass feedstock grown on municipal sewage sludge. Ind. Crops Prod. 2016, 81, 72-82. [CrossRef] 
65. Szyszlak-Bargłowicz, J.; Zając, G.; Piekarski, W. Energy biomass characteristics of chosen plants. Int. Agrophys. 2012, 26, 175-179. [CrossRef]

66. Borkowska, H.; Lipiński, W. Content of selected elements in biomass of several species of energy crops. Acta Agrophys. 2007, 10, 287-292.

67. Szyszlak-Bargłowicz, J. Content of chosen macroelements in biomass of Virginia mallow (Sida hermaphrodita Rusby). J. Cent. Eur. Agric. 2013, 15, 263-271. [CrossRef]

68. Kalembasa, D.; Malinowska, E. Follow-up activities of sewage sludge applied to the soil in the pot experiment on the content of heavy metals in grass Miscanthus sacchariflorus. Acta Agrophys. 2009, 13, 377-384.

69. Kalembasa, S.; Wysokiński, A.; Cichuta, R. Content of heavy metals in willow (Salix viminalis) wth different nitrogen fertilization. Acta Agrophys. 2009, 13, 385-392.

70. Szwalec, A.; Mundała, P.; Kędzior, R.; Telk, M.; Gawroński, P. Differentiation of Cd, Pb, Zn and Cu contents in biomass used for energy production. Acta Sci. Pol. Formatio Circumiectus 2016, 15, 343-351.

71. Polish Committee for Standardization. Soil Quality-Determination of Ph; Polish Committee for Standardization: Warsaw, Poland, 1997.

72. Polish Committee for Standardization. Chemical and Agricultural Analysis of the Soil-Determination of the Content of Absorbable Phosphorus in Mineral Soils; Polish Committee for Standardization: Warsaw, Poland, 1996.

73. Polish Committee for Standardization. Chemical and Agricultural Analysis of the Soil-Determination of the Content of Potassium in Mineral Soils; Polish Committee for Standardization: Warsaw, Poland, 2002.

74. Polish Committee for Standardization. Chemical and Agricultural Analysis of the Soil-Determination of the Content of Potassium in Mineral Soils; Polish Committee for Standardization: Warsaw, Poland, 2004.

75. British Standards Institution. Solid Biofuels-Determination of Total Carbon, Hydrogen and Nitrogen Content_Instrumental Methods; British Standards Institution: London, UK, 2011.

76. British Standards Institution. Solid Biofuels-Determination of Volatile Part Content; British Standards Institution: London, UK, 2010.

77. British Standards Institution. Solid Biofuels-Determination of Calorific Value; British Standards Institution: London, UK, 2011.

78. British Standards Institution. Solid Biofuels-Determination of Calorific Value; British Standards Institution: London, UK, 2010.

79. Saletnik, B.; Zaguła, G.; Grabek-Lejko, D.; Kasprzyk, I.; Bajcar, M.; Czernicka, M.; Puchalski, Cz. Biosorption of cadmium (II), lead (II) and cobalt (II) from aqueous solution by biochar from cones of larch (Larix decidua Mill. subsp. decidua) and spruce (Picea abies L. H. Karst). Environ. Earth Sci. 2017, 76, 574. [CrossRef]

80. Milestone. SK-10 High Pressure Rotor; HPR-EN-13 Soil Total Digestion; Milestone: Shelton, CT, USA; Available online: http:/ / subitam.sinop.edu.tr/fileman/Uploads/Subitam/Mikrodalga.pdf (accessed on 16 January 2018).

81. Milestone. SK-10 High Pressure Rotor; HPR-PE-19 Carbon Black; Milestone: Shelton, CT, USA; Available online: http:/ / subitam.sinop.edu.tr/fileman/Uploads/Subitam/Mikrodalga.pdf (accessed on 16 January 2018).

82. Milestone. SK-10 High Pressure Rotor; HPR-AG-02 Dried Plant Tissue; Milestone: Shelton, CT, USA; Available online: http:/ / subitam.sinop.edu.tr/fileman/Uploads/Subitam/Mikrodalga.pdf (accessed on 16 January 2018).

83. Milestone. SK-10 High Pressure Rotor; HPR-EN-04 Fly Ash; Milestone: Shelton, CT, USA; Available online: http:/ / subitam.sinop.edu.tr/fileman/Uploads/Subitam/Mikrodalga.pdf (accessed on 16 January 2018).

(C) 2018 by the authors. Licensee MDPI, Basel, Switzerland. This article is an open access article distributed under the terms and conditions of the Creative Commons Attribution (CC BY) license (http://creativecommons.org/licenses/by/4.0/). 